\title{
Evaluation of Starch as an Environmental-Friendly Bioresource for the Development of Wood Bioadhesives
}

\author{
Ana Arias*(D), Gumersindo Feijoo (D) and María Teresa Moreira (D) \\ CRETUS, Department of Chemical Engineering, School of Engineering, Universidade de Santiago de Compostela, \\ 15705 Santiago de Compostela, Spain; gumersindo.feijoo@usc.es (G.F.); maite.moreira@usc.es (M.T.M.) \\ * Correspondence: anaarias.calvo@usc.es
}

check for

updates

Citation: Arias, A.; Feijoo, G.; Moreira, M.T. Evaluation of Starch as an Environmental-Friendly Bioresource for the Development of Wood Bioadhesives. Molecules 2021, 26, 4526. https://doi.org/10.3390/molecules 26154526

Academic Editors: Eduardo Robles, Bertrand Charrier and

Grzegorz Kowaluk

Received: 1 July 2021

Accepted: 24 July 2021

Published: 27 July 2021

Publisher's Note: MDPI stays neutral with regard to jurisdictional claims in published maps and institutional affiliations.

Copyright: (c) 2021 by the authors. Licensee MDPI, Basel, Switzerland. This article is an open access article distributed under the terms and conditions of the Creative Commons Attribution (CC BY) license (https:// creativecommons.org/licenses/by/ $4.0 /)$.

\begin{abstract}
The environment is a very complex and fragile system in which multiple factors of different nature play an important role. Pollution, together with resource consumption, is one of the main causes of the environmental problems currently affecting the planet. In the search for alternative production processes, the use of renewable resources seeks a way to satisfy the demands of resource consumption based on the premises of lower environment impact and less damage to human health. In the wood sector, the panel manufacturing process is based on the use of formaldehydebased resins. However, their poor moisture resistance leads to hydrolysis of amino-methylene bonds, which induces formaldehyde emissions throughout the lifetime of the wood panel. This manuscript investigates the environmental profile associated with different wood bioadhesives based on starch functionalization as a renewable alternative to formaldehyde resins. Considering that this is a process under development, the conceptual design of the full-scale process will be addressed by process modeling and the environmental profile will be assessed using life cycle assessment methodology. A comparative study with synthetic resins will provide useful information for modify their development to become real alternatives in the wood-based panel industry. The results obtained show the enormous potential of starch bioadhesives, as their environmental impact values are lower compared to those based on petrochemicals. However, certain improvements in the energy process requirements and in the chemical agents used could be developed to provide even better results.
\end{abstract}

Keywords: starch bioadhesives; chemical modification of starch; wood bioadhesives; life cycle assessment; environmental sustainability; formaldehyde-free wood adhesives

\section{Introduction}

Formaldehyde is an aldehyde with high flammability and volatility potential, produced from the dehydrogenation and catalytic oxidation of methanol [1]. It is one of the most widely used crosslinking agents in the wood-based panel manufacturing industry, given its ease of processing, wide availability, low cost and high reactivity [2,3], representing a reference alternative in the wood production sector based on its technical and economic efficiency. However, environmental and health implications have to be taken into account as it is categorized in the REACH list as a carcinogen (category 1B) and mutagen (category 2). In particular, the main sources of hazard identified for formaldehyde are related to its atmospheric emissions and its potential harm to human health, in addition to the impacts caused by its production process (GHG emissions, consumption of nonrenewable fossil resources, toxicity, etc.). Given the reasons listed above, in recent years strict legal requirements have been developed in relation to the emission limits considered for formaldehyde, so that emission levels below $0.3 \mathrm{mg} / \mathrm{L}$ must be ensured [4] or by considering adhesives formulated with hardeners or scavengers that prevent or reduce the release of formaldehyde from the wood panel product [5-9].

The alternative based on renewable raw materials for the development of bioadhesives has been considered as an option of special interest. These include the use of 
soy [10-12], tannins [13-15], lignin [16-18], wood fibers [19,20], plant polymers [21,22] and starch [23-25]. In particular, starch is the second most abundant lignocellulosic polymer in nature [26]. Moreover, it is a low-cost resource with high potentiality, since it is biodegradable. However, despite these advantages, its direct use, i.e., as "native starch", is not feasible for the development of bioadhesives for wood, since the large amount of hydrophilic hydroxyl groups in its molecular structure leads to low tolerance to moisture and high water absorption capacity [19]. In addition, it is necessary to provide active centers in its structure to improve adhesion strength and, in turn, control viscosity and morphological properties [27]. Therefore, a pretreatment is required to reduce the amount of hydroxyl groups present in their structure by adding crosslinking agents [26]. Thus, four bioadhesive alternatives will be evaluated in which different processing techniques have been considered, thus increasing their potential to be employed in the manufacture of wood-based panels. Considering the above, a large-scale design was carried out, including mass and energy balances based on laboratory data reported in the literature. A production capacity of $1000 \mathrm{~kg} / \mathrm{h}$ of bioadhesive was considered, in which a production process analogous to that of the most commonly used synthetic resins (urea-formaldehyde, phenol-formaldehyde and melamine-urea-formaldehyde) can be established [28].

On the other hand, it is also important to study their potential from an environmental point of view. Once the input and output flows were estimated, the life cycle assessment (LCA) methodology was applied to evaluate the environmental impacts associated with each of the proposed starch bioadhesives [29]. For its application, it is necessary to define the inventory in which all the components included in the product/process are quantified, the system boundaries and the calculation methodology. Thus, a comparative analysis has been carried out with the most widely used synthetic-based resins, whose production processes are fully optimized. The evaluation of improvements or weaknesses in terms of the environmental impacts of their production processes has also been considered.

The objective of this research article is to evaluate four starch bioadhesives as alternatives to synthetic resins for the adhesion of wood-based panels, using a combination of process modeling and LCA methodology. The production capacity considered was $1000 \mathrm{~kg} / \mathrm{batch}$ of bioadhesive and the functional unit was the production of $1 \mathrm{~kg}$ of bioadhesive, the basis of calculation to refer all inputs and outputs of the system.

The development of LCA studies involves a series of categorized and interrelated steps in a circular perspective: definition of goal and scope, inventory analysis, impact assessment and interpretation of results. The functional unit (FU) as defined by ISO is the quantified performance of a product system and its value must be consistent with the objective of the assessment and fully measurable [30]. The scope of the study has been selected within a "cradle-to-gate" approach. Thus, the LCA study is developed from the extraction of all necessary inputs in the process to the moment the product is ready for market. Therefore, transport activities, the use of the product by the consumer and the processes associated with its recycling, recovery or final disposal are outside the scope of the study. This approach has been considered appropriate as it allows not only for a comprehensive environmental analysis of the processes under development but also establishes a framework for completing environmental product declarations (EPDs) [31].

Regarding the database used for the analysis, Ecoinvent has been selected for conducting the life-cycle inventories, as it includes basic information on the main inputs, both material and energy, and outputs [32]. The calculation method considered for the development of the LCA was Recipe 2016, a methodology with a hierarchist perspective that includes both midpoint and endpoint indicators.

\section{Materials and Methods}

\subsection{Description of the Four Bioadhesive Processes}

Two main starch pretreatment methods have been considered for the analysis: hydrolysis and oxidation. 


\subsubsection{Pretreatment Method 1: Starch Hydrolysis}

The acid hydrolysis of starch leads to a reduction of its molecular weight, as it is broken down into its monomeric units: amylose and amylopectin. Specifically, amylose is hydrolyzed by cleavage of the $\alpha-1-4$ bond and amylopectin by the $\alpha-1-4$ bond [33], using $\mathrm{HCl}$ at low temperature, specifically, at a temperature below gelatinization [34]. In this way, a double objective is achieved, on the one hand, the formation of a greater number of active centers for the subsequent polymerization reactions with the crosslinking agents and, on the other hand, a reduction in viscosity, which is a decisive factor in the mechanical properties required for the application of the bioadhesive [35]. After acid hydrolysis, polymerization proceeds, which requires the development of a grafting process, based on the addition of monomeric units that will be joined by covalent bonds to the amylose and amylopectin units [36]. There are different grafting methods, the most widely used are free-radical grafting (FRG), as it is the simplest and cheapest way to modify biopolymers [37], in which grafting induced by chemical initiators has been chosen for its simplicity and efficiency. The most used initiating agents are sulfate salts (ammonium sulfate, ferrous sulfate), nitrate salts (ceric ammonium nitrate) and also Fenton chemicals [36]. After this first stage, the formation of reactive centers in the amylose and amylopectin polymers is achieved, to which the monomers selected for the adhesive formulation such as polyvinyl alcohol, vinyl acetate or butyl acrylate will be attached. In this way, a polymerization process takes place, thus improving the mechanical properties of the starch-based bioadhesive.

\section{Alternative 1. Hydrolyzed Starch Bioadhesive with Bio-Oil}

This alternative considers cassava starch, which has certain advantages over other starch sources, since it has a lower gelatinization temperature, which favors less energydemanding processes, and also stands out for its structural stability and thermogravimetric properties [38,39]. After acid hydrolysis at a temperature of $60^{\circ} \mathrm{C}$, the grafting process proceeds, using $\left(\mathrm{NH}_{4}\right)_{2} \mathrm{SO}_{4}$ as the initiating agent. The monomers that bind to the starch structure in the polymerization process are polyvinyl alcohol (PVA), which binds through hydrogen bonds [39], vinyl acetate and butyl acrylate, which bind through the free hydroxyl radicals of amylose and amylopectin [40]. After this first polymerization, a second one is carried out in the pursuit to improve the thermogravimetric properties of the starch bioadhesive. For this, it is required, again, to add an initiating agent, the same as for the first polymerization step (ammonium sulfate). Then, bio-oil is slowly added, which will react with the free hydroxyl groups of the amylose and amylopectin units and bind by the formation of ether bonds [41]. The reason for adding this bio-oil is that its presence in the structure of the bioadhesive improves its properties: greater stability and resistance to external agents [42], such as humidity or temperature variations.

\section{Alternative 2. Starch Bioadhesive Hydrolyzed with N-Methylol Acrylamide}

The second starch bioadhesive alternative is carried out based on three main steps in the formulation procedure: starch pretreatment based on acidolysis with $\mathrm{HCl}$, followed by linear polymerization, considering the use of three polymers: sodium dodecyl sulfate (SDS), ammonium persulfate (APS) and vinyl acetate (VAc) for $3.5 \mathrm{~h}$ at $70{ }^{\circ} \mathrm{C}$, and finally the formation of a network polymer, by the addition of N-methylol acrylamide (NMA), requiring $4.5 \mathrm{~h}$ and $85^{\circ} \mathrm{C}$ [43]. Another aspect to take into account is the thermal variability that requires each stage of the process. While acidolysis starts at $60^{\circ} \mathrm{C}$, it subsequently evolves until it reaches $90^{\circ} \mathrm{C}$. In the case of the linear starch polymerization stage, the process starts at $70{ }^{\circ} \mathrm{C}$ and increases to $85^{\circ} \mathrm{C}$ in the last $30 \mathrm{~min}$ to favor the process yield, and finally a decrease to $50^{\circ} \mathrm{C}$ to obtain the final bioadhesive ready for application on wood panels. As for the type of bond formed between the starch polymer and N-methylol acrylamide, these are strong hydrogen bonds, which favors the improvement of the mechanical properties of the final bioadhesive, especially in terms of shear and water resistance [44]. 


\subsubsection{Pretreatment Method 2: Oxidation of Starch}

Pretreatment by oxidation is also commonly employed for structural modification of the native starch molecule. However, it occupies the second position in terms of preference, since it can lead to partial depolymerization [45], which does not occur for acid hydrolysis. The result of this pretreatment is the formation of carboxylic groups or aldehydes from the oxidation of the primary and secondary hydroxyl groups of the glucose units that make up the amylose and amylopectin polymers [46]. The oxidation of native starch involves the loss of its crystallization, leading to the weakening of hydrogen bonds, which will facilitate the bonding of monomeric units in the subsequent polymerization process [47].

This oxidative process is going to require the presence of oxidizing chemicals, such as organic (i.e., $\mathrm{NaClO})$ or inorganic $\left(\mathrm{H}_{2} \mathrm{O}_{2}\right)$ peroxides, nitrogen $\left(\mathrm{HNO}_{2}\right)$ or metal $\left(\mathrm{CrO}_{3}\right)$ compounds, together with a catalyst, which will be transition metals in cationic form [46]. However, the choice of one or the other should focus not only on the performance of the oxidation process, but also on the environmental impacts they may generate. While hydrogen peroxide could be considered as the most "environmental-friendly", the use of metal compounds as oxidizing agents would be the least suitable, from an environmental point of view, since the release of heavy metals into the environment leads to significant environmental impacts [48]. After this first oxidative pretreatment, the polymerization process proceeds, analogous to that presented above for the case of acid hydrolysis pretreatment.

Alternative 3. Starch Bioadhesive Oxidized with $\mathrm{FeSO}_{4}$ and $\mathrm{H}_{2} \mathrm{O}_{2}$

This third alternative is based on the development of a Fenton-type reaction, in which $\mathrm{Fe}^{2+}$ is oxidized to $\mathrm{Fe}^{3+}$ in the presence of hydrogen peroxide, which is transformed into a hydroxyl radical (Reaction 1). The presence of this radical will result in the oxidation of starch as it reacts with the hydroxyl groups of the glucose units, leading to the creation of carboxylic groups and aldehydes [49].

$$
\mathrm{H}_{2} \mathrm{O}_{2}+\mathrm{Fe}^{2+} \rightarrow \mathrm{Fe}^{3+}+\mathrm{OH}^{-}+\mathrm{OH}^{\bullet}
$$

After this first pretreatment step, polymerization is carried out with the following chemicals: PVA, sodium dodecyl sulfate (SDS), ammonium persulfate (APS), silane coupling agent, butyl acrylate (BAc) and vinyl acetate (VAc) [50] due to a number of reasons: good adhesive strength [29], better dispersion [51,52], higher adhesion strength, better viscosity [53,54], water resistance [55] and thermal stability [56].

\section{Alternative 4. Starch Bioadhesive Oxidized with $\mathrm{NaClO}$ and $\mathrm{ECH}$}

Unlike Alternative 3, in this last starch bioadhesive option, the oxidative pretreatment considers the use of $\mathrm{NaClO}$. In this case, the hypochlorite ion $\left(\mathrm{ClO}^{-}\right)$oxidizes the starch molecule by removing the hydrogen atom from the hydroxyl groups and the consequent formation of the carboxylic or ketone groups (Reaction 2). With this transformation of the molecular structure of starch, an increase in the polarity of the molecule is achieved and a greater facility for the development of the grafting process and subsequent polymerization [57].

$$
\text { Starch }-\mathrm{OH}+\mathrm{OCl}^{-} \rightarrow \text { Starch }=\mathrm{O}+\mathrm{H}_{2} \mathrm{O}+\mathrm{Cl}^{-}
$$

In this study, in addition to including $\mathrm{NaClO}$ in this first stage of activation, it also utilizes epichlorohydrin (ECH) [58], which binds to the starch molecule through the formation of diether bridges developing a crosslinking reaction [59]. PVA, sodium lauryl sulfate (LSS), Tween 80, APS and VAc are also included in the formulation of this bioadhesive. The advantages of using LSS as an emulsifying compound are based on an improvement in the stability of the adhesive compound, in addition to an increase in shear strength [60]. As for Tween 80, it is a surfactant used to reduce surface tension and improve wetting in the board-adhesive bonding process [61]. 


\subsection{System Boundaries}

All the stages regarding the extraction of raw materials, the production of the bioadhesive and the emissions and waste management have been considered within the system boundaries of the LCA analysis (Figure 1). On the other hand, transport activities and infrastructure process were excluded and, as it has been considered a cradle-to-gate approach for the assessment, also the bioadhesive's uses and its end-of-life stages are out of the system boundaries.

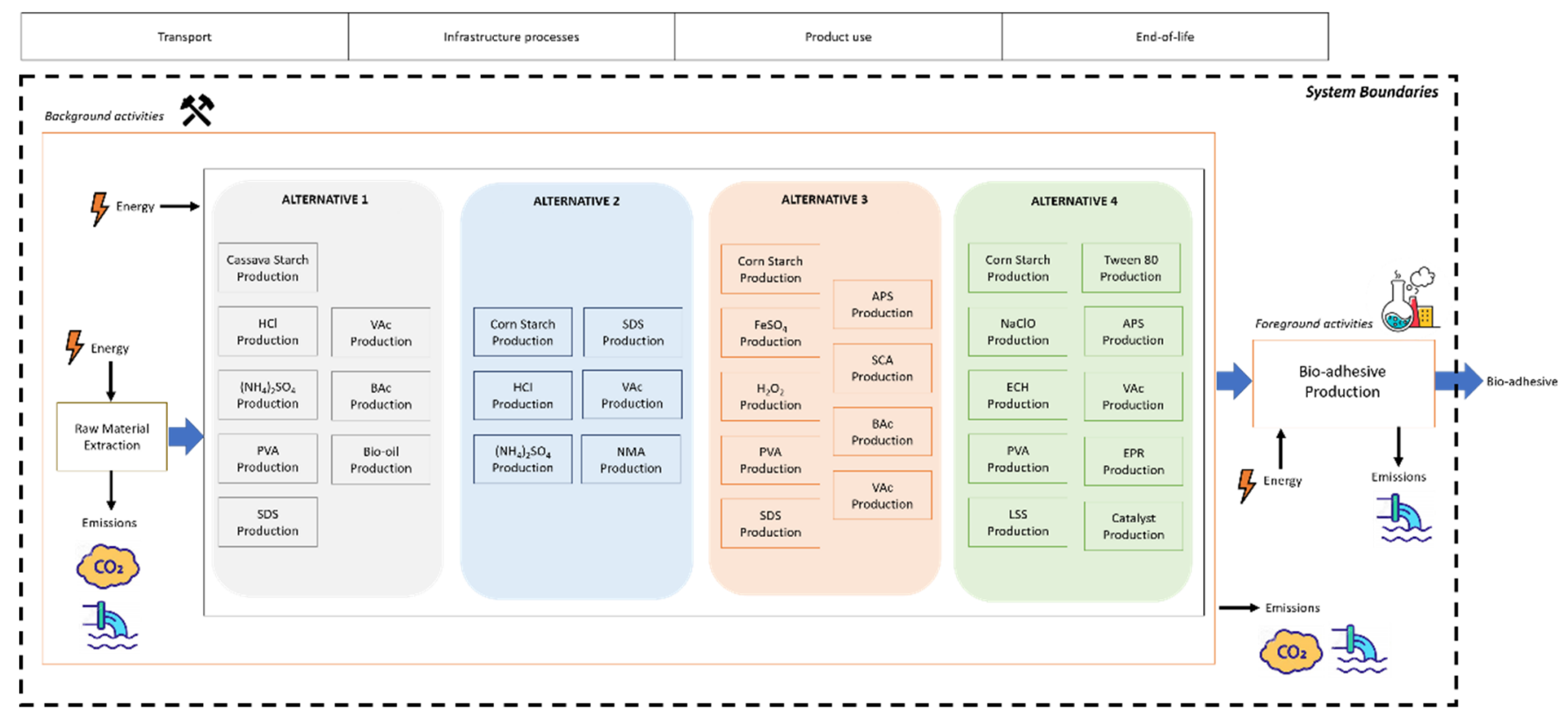

Figure 1. System boundaries of the bioadhesives' production considered for LCA analysis.

\subsection{LCA Inventories}

The inventories considered for each of the starch bioadhesive alternatives are shown in Tables 1-4, including the inputs required from the technosphere, both materials and energy requirements, and the outputs to the technosphere, which comprise the main product, the bioadhesive, and the emissions associated with its production.

Table 1. Inventory data for the production of hydrolyzed starch bioadhesive with bio-oil (Alternative 1). Detailed data per functional unit (1 kg of bioadhesive). Acronyms: polyvinyl alcohol (PVA), sodium dodecyl sulfate (SDS), vinyl acetate (VAc), butyl acrylate (BAc).

\begin{tabular}{|c|c|c|c|c|c|}
\hline \multicolumn{3}{|c|}{ Inputs from Technosphere } & \multicolumn{3}{|c|}{ Outputs to Technosphere } \\
\hline \multicolumn{3}{|c|}{ Materials } & \multicolumn{3}{|c|}{ Products } \\
\hline Cassava starch & 0.354 & $\mathrm{~kg}$ & \multirow{3}{*}{ Bioadhesive } & \multirow{3}{*}{1} & \multirow{3}{*}{$\mathrm{kg}$} \\
\hline $\mathrm{HCl}$ & 0.010 & $\mathrm{~kg}$ & & & \\
\hline$\left(\mathrm{NH}_{4}\right)_{2} \mathrm{SO}_{4}$ & 0.022 & $\mathrm{~kg}$ & & & \\
\hline PVA & 0.042 & $\mathrm{~kg}$ & \multicolumn{3}{|c|}{ Emissions to water } \\
\hline SDS & 0.008 & $\mathrm{~kg}$ & \multirow{2}{*}{$\mathrm{NH}_{4} \mathrm{Cl}$} & \multirow{2}{*}{0.014} & \multirow{2}{*}{$\mathrm{kg}$} \\
\hline VAc & 0.051 & $\mathrm{~kg}$ & & & \\
\hline BAc & 0.034 & $\mathrm{~kg}$ & \multirow{2}{*}{$\mathrm{H}_{2} \mathrm{SO}_{4}$} & \multirow{2}{*}{0.013} & \multirow{2}{*}{$\mathrm{kg}$} \\
\hline Bio-oil & 0.088 & $\mathrm{~kg}$ & & & \\
\hline Water & 0.439 & $\mathrm{~kg}$ & \multirow{2}{*}{$\mathrm{H}_{2} \mathrm{O}$} & \multirow{2}{*}{0.017} & \multirow{2}{*}{$\mathrm{kg}$} \\
\hline & ergy & & & & \\
\hline Electricity & 0.12 & $\mathrm{kWh}$ & \multirow{2}{*}{$\left(\mathrm{NH}_{4}\right)_{2} \mathrm{SO}_{4}$} & \multirow{2}{*}{0.005} & \multirow{2}{*}{$\mathrm{kg}$} \\
\hline Heat & 58.76 & $\mathrm{~kJ}$ & & & \\
\hline
\end{tabular}


Table 2. Inventory data for the production of hydrolyzed starch bioadhesive with N-methylol acrylamide (NMA) (Alternative 2). Detailed data per functional unit (1 kg of bioadhesive). Acronyms: sodium dodecyl sulfate (SDS), vinyl acetate (VAc), N-methyl acrylamide (NMA).

\begin{tabular}{|c|c|c|c|c|c|}
\hline \multicolumn{3}{|c|}{ Inputs from Technosphere } & \multicolumn{3}{|c|}{ Outputs to Technosphere } \\
\hline \multicolumn{3}{|c|}{ Materials } & \multicolumn{3}{|c|}{ Products } \\
\hline Corn starch & 0.442 & $\mathrm{~kg}$ & \multirow{3}{*}{ Bioadhesive } & \multirow{3}{*}{1} & \multirow{3}{*}{$\mathrm{kg}$} \\
\hline $\mathrm{HCl}$ & 16.146 & $\mathrm{~g}$ & & & \\
\hline$\left(\mathrm{NH}_{4}\right)_{2} \mathrm{SO}_{4}$ & 5.087 & $\mathrm{~g}$ & & & \\
\hline SDS & 5.773 & $\mathrm{~g}$ & \multicolumn{3}{|c|}{ Emissions to water } \\
\hline VAc & 0.310 & $\mathrm{~kg}$ & \multirow{2}{*}{$\mathrm{NH}_{4} \mathrm{Cl}$} & \multirow{2}{*}{6.732} & \multirow{2}{*}{$\mathrm{g}$} \\
\hline NMA & 11.059 & $\mathrm{~g}$ & & & \\
\hline Water & 0.496 & $\mathrm{~kg}$ & $\mathrm{H}_{2} \mathrm{SO}_{4}$ & 32.938 & $\mathrm{~g}$ \\
\hline \multicolumn{3}{|c|}{ Energy } & \multirow{2}{*}{$\mathrm{HCl}$} & \multirow{2}{*}{94.576} & \multirow{2}{*}{$\mathrm{g}$} \\
\hline Electricity & 1.453 & $\mathrm{kWh}$ & & & \\
\hline Heat, steam & 86.63 & $\mathrm{~kJ}$ & \multirow{2}{*}{$\mathrm{NaCl}$} & \multirow{2}{*}{0.151} & \multirow{2}{*}{$\mathrm{kg}$} \\
\hline Cooling energy & 94.52 & $\mathrm{~kJ}$ & & & \\
\hline
\end{tabular}

Table 3. Inventory data for the production of starch bioadhesive oxidized with $\mathrm{FeSO}_{4}$ and $\mathrm{H}_{2} \mathrm{O}_{2}$ (Alternative 3). Detailed data per functional unit (1 kg of bioadhesive). Acronyms: polyvinyl alcohol (PVA), sodium dodecyl sulfate (SDS), ammonium persulfate (APS), silane coupling agent (SCA), vinyl acetate (VAc), butyl acrylate (BAc).

\begin{tabular}{|c|c|c|c|c|c|}
\hline \multicolumn{3}{|c|}{ Inputs from Technosphere } & \multicolumn{3}{|c|}{ Outputs to Technosphere } \\
\hline \multicolumn{3}{|c|}{ Materials } & \multicolumn{3}{|c|}{ Products } \\
\hline Corn starch & 0.064 & $\mathrm{~kg}$ & \multirow{3}{*}{ Bioadhesive } & \multirow{3}{*}{1} & \multirow{3}{*}{$\mathrm{kg}$} \\
\hline Water & 0.636 & $\mathrm{~kg}$ & & & \\
\hline $\mathrm{FeSO}_{4}$ & 0.636 & $\mathrm{~g}$ & & & \\
\hline $\mathrm{H}_{2} \mathrm{O}_{2}$ & 0.636 & $\mathrm{~g}$ & \multicolumn{3}{|c|}{ Emissions to water } \\
\hline PVA & 0.019 & $\mathrm{~kg}$ & \multirow{2}{*}{$\mathrm{FeH}_{3}$} & \multirow{2}{*}{0.234} & \multirow{2}{*}{$\mathrm{g}$} \\
\hline SDS & 0.636 & $\mathrm{~g}$ & & & \\
\hline APS & 0.636 & $\mathrm{~g}$ & \multirow{4}{*}{$\mathrm{H}_{2} \mathrm{SO}_{4}$} & \multirow{4}{*}{0.402} & \multirow{4}{*}{$\mathrm{g}$} \\
\hline SCA & 0.318 & $\mathrm{~g}$ & & & \\
\hline BAc & 0.136 & $\mathrm{~kg}$ & & & \\
\hline VAc & 0.143 & $\mathrm{~kg}$ & & & \\
\hline \multicolumn{3}{|c|}{ Energy } & & & \\
\hline Electricity & 0.272 & kWh & & & \\
\hline Heat, steam & 62.92 & $\mathrm{~kJ}$ & & & \\
\hline Cooling energy & 197.98 & $\mathrm{~kJ}$ & & & \\
\hline
\end{tabular}

\subsection{LCA Parameters}

The calculation methodologies selected to perform the life cycle assessment of the starch bioadhesives were the following: ReCiPe Midpoint (H) V1.03 World (2010), ReCiPe Endpoint (H/H) V1.03 World (2010) and USEtox V1.04 Europe (2004). The impact categories considered for study in this article are displayed on Table 5. 
Table 4. Inventory data for the production of starch bioadhesive oxidized with $\mathrm{NaClO}$ and $\mathrm{ECH}$ (Alternative 4). Detailed data per functional unit (1 kg of bioadhesive). Acronyms: epichlorohydrin $(\mathrm{ECH})$, polyvinyl alcohol (PVA), lauryl sodium sulfate (LSS), ammonium persulfate (APS), vinyl acetate (VAc), epoxy resin (EPR).

\begin{tabular}{|c|c|c|c|c|c|}
\hline \multicolumn{3}{|c|}{ Inputs from Technosphere } & \multicolumn{3}{|c|}{ Outputs to Technosphere } \\
\hline \multicolumn{3}{|c|}{ Materials } & \multicolumn{3}{|c|}{ Products } \\
\hline Corn starch & 0.131 & $\mathrm{~kg}$ & \multirow{3}{*}{ Bioadhesive } & \multirow{3}{*}{1} & \multirow{3}{*}{$\mathrm{kg}$} \\
\hline Water & 0.411 & $\mathrm{~kg}$ & & & \\
\hline $\mathrm{NaClO}$ & 1.969 & $\mathrm{~g}$ & & & \\
\hline $\mathrm{ECH}$ & 2.626 & g & \multicolumn{3}{|c|}{ Emissions to water } \\
\hline PVA & 0.022 & $\mathrm{~kg}$ & \multirow{2}{*}{$\mathrm{NaCl}$} & \multirow{2}{*}{0.827} & \multirow{2}{*}{$\mathrm{g}$} \\
\hline LSS & 2.740 & $\mathrm{~g}$ & & & \\
\hline Tween80 & 4.110 & $\mathrm{~g}$ & \multirow{2}{*}{$\mathrm{HCl}$} & \multirow{2}{*}{1.119} & \multirow{2}{*}{$\mathrm{g}$} \\
\hline APS & 2.814 & $\mathrm{~g}$ & & & \\
\hline VAc & 0.192 & $\mathrm{~kg}$ & \multirow{3}{*}{$\mathrm{H}_{2} \mathrm{SO}_{4}$} & \multirow{3}{*}{0.912} & \multirow{3}{*}{$\mathrm{g}$} \\
\hline EPR & 0.221 & $\mathrm{~kg}$ & & & \\
\hline Catalyst & 0.012 & $\mathrm{~kg}$ & & & \\
\hline \multicolumn{3}{|c|}{ Energy } & & & \\
\hline Electricity & 0.288 & $\mathrm{kWh}$ & & & \\
\hline Heat, steam & 58.39 & $\mathrm{~kJ}$ & & & \\
\hline Cooling energy & 18.16 & $\mathrm{~kJ}$ & & & \\
\hline
\end{tabular}

Table 5. Impact categories selected for performing LCA, including its acronyms and units.

\begin{tabular}{|c|c|c|c|}
\hline Method & Impact Category & Acronym & Unit \\
\hline \multirow{11}{*}{ ReCiPe Midpoint (H) } & Global Warming & GW & $\mathrm{kg} \mathrm{CO} 2 \mathrm{eq}$ \\
\hline & Stratospheric Ozone Depletion & SOD & $\mathrm{mg} \mathrm{CFC}_{11} \mathrm{eq}$ \\
\hline & Ozone Formation & $\mathrm{OF}$ & $\mathrm{g} \mathrm{NO}_{\mathrm{x}} \mathrm{eq}$ \\
\hline & Terrestial Acidification & TA & $\mathrm{g} \mathrm{SO}_{2} \mathrm{eq}$ \\
\hline & Freshwater Eutrophication & $\mathrm{FE}$ & g P eq \\
\hline & Marine Eutrophication & ME & g N eq \\
\hline & Terrestial Ecotoxicity & TET & $\mathrm{kg} 1,4$-DCB \\
\hline & Freshwater Ecotoxicity & FET & g 1,4-DCB \\
\hline & Marine Ecotoxicity & MET & g 1,4-DCB \\
\hline & Mineral Resource Scarcity & MRS & g Cu eq \\
\hline & Fossil Resource Scarcity & FRS & kg oil eq \\
\hline \multirow{3}{*}{ ReCiPe Endpoint (H/H) } & Human Health & $\mathrm{HH}$ & $\mathrm{mPt}$ \\
\hline & Ecosystems & $\mathrm{E}$ & $\mathrm{mPt}$ \\
\hline & Resources & $\mathrm{R}$ & $\mathrm{mPt}$ \\
\hline \multirow{2}{*}{ USEtox } & $\mathrm{HT}, \mathrm{c}$ & HT, c & CTUh \\
\hline & $\mathrm{HT}, \mathrm{nc}$ & $\mathrm{HT}, \mathrm{nc}$ & CTUh \\
\hline
\end{tabular}

\section{Results and Discussion}

\subsection{Environmental Profiles of Starch Bioadhesive Alternatives}

\subsubsection{Alternative 1. Hydrolyzed Starch Bioadhesive with Bio-Oil}

The environmental impacts are shown in Table 6 and the profile of this starch bioadhesive alternative is shown in Figure 2.

There is some variability in the environmental contribution according to the impact categories, although three main hotspots can be identified: the production of the cassava starch, the electricity requirements and the emissions from the bioadhesive formulation. The reason for the significant environmental contribution of starch is attributed to cassava cultivation due to the direct emissions of $\mathrm{CO}_{2}$, ammonia and nitrates as a consequence of the use of fertilizers in the crop field and the generation of crop residues, and the use of diesel fuel for agricultural machinery. 


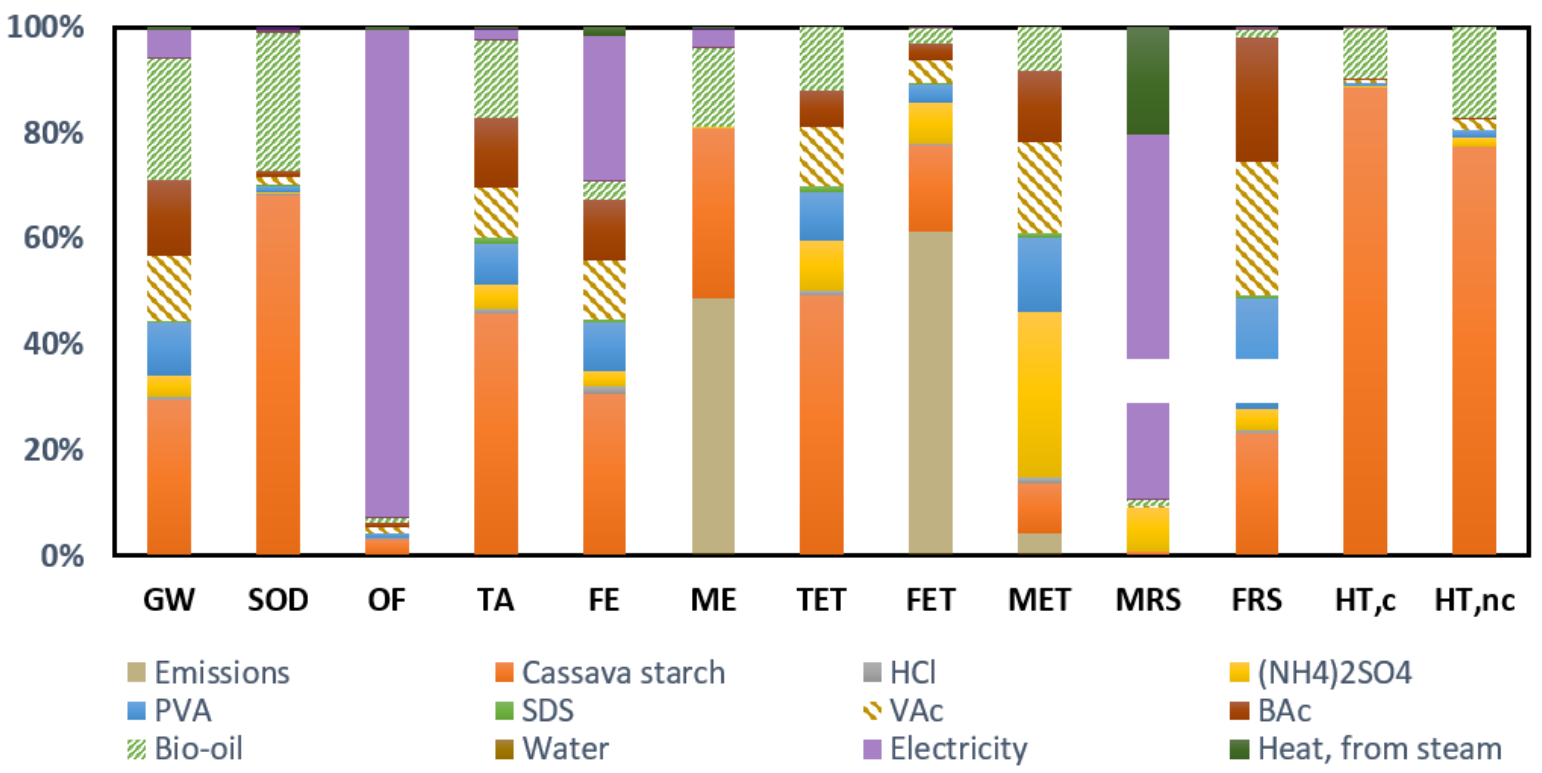

Figure 2. Environmental profile of the hydrolyzed starch bioadhesive with bio-oil (Alternative 1).

As for emissions, they are characterized by ammonium compounds, specifically ammonium chloride and ammonium sulfate, as well as sulfuric acid. While ammonium species cause eutrophication [62], the implication of sulfuric acid can cause variations in the $\mathrm{pH}$ of the aquatic environment, with a moderate toxicity potential [63].

The impact of the electricity needs of the production process of this bioadhesive alternative is noteworthy in the MRS and OF categories. The reason for its contribution in the MRS category is associated with the production of electricity from nonrenewable fossil resources. As for the OF category, energy consumption involves the formation of atmospheric ozone as a product of the reaction between nitrogen oxides and volatile organic compounds, when exposed to sunlight [64].

\subsubsection{Alternative 2. Hydrolyzed Starch Bioadhesive with N-Methyl Acrylamide}

A certain analogy can be observed in the environmental profile of this option compared to the results shown previously (Table 7 and Figure 3).

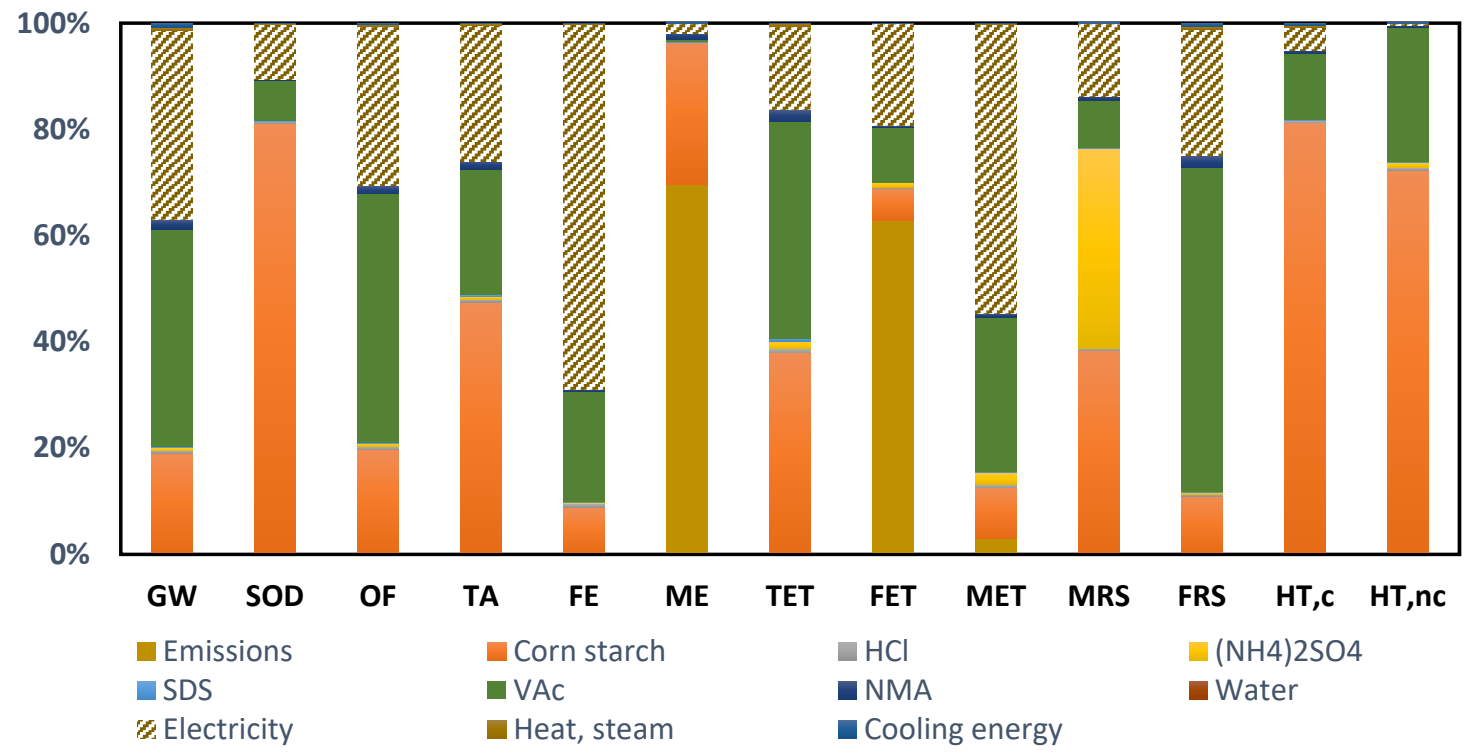

Figure 3. Environmental profile of the hydrolyzed starch bioadhesive with N-methyl acrylamide (Alternative 2). 
Table 6. Environmental characterization of hydrolyzed starch bioadhesive with bio-oil.

\begin{tabular}{|c|c|c|c|c|c|c|c|c|c|c|c|c|c|c|}
\hline $\begin{array}{l}\text { Impact } \\
\text { Category }\end{array}$ & Unit & Total & Emissions & $\begin{array}{c}\text { Cassava } \\
\text { Starch }\end{array}$ & $\mathrm{HCl}$ & $\left(\mathrm{NH}_{4}\right)_{2} \mathrm{SO}_{4}$ & PVA & SDS & VAc & BAc & Bio-oil & Water & Electricity & $\begin{array}{c}\text { Heat, from } \\
\text { Steam }\end{array}$ \\
\hline GW & $\mathrm{kgCO}_{2} \mathrm{eq}$ & 0.92 & & 0.27 & $5.08 \times 10^{-3}$ & 0.03 & 0.09 & $4.65 \times 10^{-3}$ & 0.11 & 0.13 & 0.21 & $0.1 \times 10^{-3}$ & 0.05 & $6.06 \times 10^{-3}$ \\
\hline SOD & $\mathrm{mg} \mathrm{CFC}_{11} \mathrm{eq}$ & 2.92 & & 1.99 & $6.45 \times 10^{-3}$ & 0.01 & 0.03 & $1.83 \times 10^{-3}$ & 0.04 & 0.04 & 0.77 & $5.74 \times 10^{-5}$ & 0.03 & $1.48 \times 10^{-3}$ \\
\hline $\mathrm{OF}$ & $\mathrm{g} \mathrm{NO}_{\mathrm{x}} \mathrm{eq}$ & 2.05 & & 0.89 & 0.01 & 0.07 & 0.22 & 0.01 & 0.27 & 0.25 & 0.23 & $0.19 \times 10^{-3}$ & 25.41 & 0.14 \\
\hline TA & $\mathrm{g} \mathrm{SO}_{2} \mathrm{eq}$ & 3.67 & & 1.64 & 0.03 & 0.15 & 0.28 & 0.05 & 0.34 & 0.46 & 0.52 & $0.42 \times 10^{-3}$ & 0.09 & $6.98 \times 10^{-3}$ \\
\hline FE & g P eq & 0.24 & & 0.08 & $3.48 \times 10^{-3}$ & $7.67 \times 10^{-3}$ & 0.02 & $1.92 \times 10^{-3}$ & 0.03 & 0.03 & $9.04 \times 10^{-3}$ & $9.05 \times 10^{-5}$ & 0.07 & $4.52 \times 10^{-3}$ \\
\hline ME & g N eq & 2.17 & 1.10 & 0.73 & $0.38 \times 10^{-3}$ & $0.49 \times 10^{-3}$ & $1.66 \times 10^{-3}$ & $0.27 \times 10^{-3}$ & $2.01 \times 10^{-3}$ & $2.00 \times 10^{-3}$ & 0.33 & $6.71 \times 10^{-6}$ & 0.09 & $7.16 \times 10^{-3}$ \\
\hline TET & $\operatorname{kg} 1,4-\mathrm{DCB}$ & 1.37 & & 0.66 & 0.01 & 0.13 & 0.12 & 0.02 & 0.15 & 0.09 & 0.16 & $8.67 \times 10^{-5}$ & $0.19 \times 10^{-3}$ & $1.36 \times 10^{-5}$ \\
\hline FET & g 1,4-DCB & 33.49 & 19.76 & 5.28 & 0.09 & 2.52 & 1.12 & 0.06 & 1.36 & 1.05 & 0.95 & $2.59 \times 10^{-3}$ & 0.05 & $0.57 \times 10^{-3}$ \\
\hline MRS & g Cu eq & 4.40 & & 0.33 & $3.59 \times 10^{-3}$ & 3.51 & 0.03 & $3.14 \times 10^{-3}$ & 0.04 & 0.06 & 0.40 & $0.27 \times 10^{-3}$ & 29.04 & 8.59 \\
\hline FRS & kg oil eq & 0.28 & & 0.06 & $1.65 \times 10^{-3}$ & 0.01 & 0.05 & $1.63 \times 10^{-3}$ & 0.07 & 0.06 & $3.85 \times 10^{-3}$ & $2.69 \times 10^{-5}$ & $1.27 \times 10^{-3}$ & $1.84 \times 10^{-5}$ \\
\hline $\mathrm{HT}, \mathrm{c}$ & $10^{-10}$ CTUh & 7.14 & & 6.32 & $4.39 \times 10^{-3}$ & 0.01 & 0.04 & $2.36 \times 10^{-3}$ & 0.05 & 0.03 & 0.67 & $2.36 \times 10^{-5}$ & $7.82 \times 10^{-3}$ & $3.87 \times 10^{-3}$ \\
\hline HT, nc & $10^{-10}$ CTUh & 10.17 & & 7.86 & 0.01 & 0.18 & 0.15 & $6.33 \times 10^{-3}$ & 0.18 & 0.04 & 1.75 & $1.66 \times 10^{-5}$ & $1.75 \times 10^{-3}$ & $0.28 \times 10^{-3}$ \\
\hline
\end{tabular}

Table 7. Environmental characterization of hydrolyzed starch bioadhesive with N-methylol acrylamide.

\begin{tabular}{|c|c|c|c|c|c|c|c|c|c|c|c|c|c|}
\hline $\begin{array}{l}\text { Impact } \\
\text { Category }\end{array}$ & Unit & Total & Emissions & Corn starch & $\mathrm{HCl}$ & $\left(\mathrm{NH}_{4}\right)_{2} \mathrm{SO}_{4}$ & SDS & VAc & NMA & Water & Electricity & Heat, Steam & $\begin{array}{l}\text { Cooling } \\
\text { Energy }\end{array}$ \\
\hline GW & $\mathrm{kgCO}_{2} \mathrm{eq}$ & 1.67 & & 0.32 & $8.21 \times 10^{-3}$ & $9.14 \times 10^{-3}$ & $3.35 \times 10^{-3}$ & 0.68 & 0.03 & $1.13 \times 10^{-4}$ & 0.60 & $8.93 \times 10^{-3}$ & 0.01 \\
\hline SOD & $\operatorname{mg} C F C_{11}$ eq & 3.24 & & 2.63 & 0.01 & $3.00 \times 10^{-3}$ & $1.32 \times 10^{-3}$ & 0.25 & $6.24 \times 10^{-3}$ & $6.49 \times 10^{-5}$ & 0.34 & $2.19 \times 10^{-3}$ & $3.98 \times 10^{-3}$ \\
\hline $\mathrm{OF}$ & $\mathrm{g} \mathrm{NO}_{\mathrm{x}} \mathrm{eq}$ & 3.46 & & 0.68 & 0.02 & 0.02 & $8.71 \times 10^{-3}$ & 1.62 & 0.05 & $2.18 \times 10^{-4}$ & 1.04 & 0.01 & 0.01 \\
\hline TA & $\mathrm{g} \mathrm{SO}_{2} \mathrm{eq}$ & 8.70 & & 4.13 & 0.05 & 0.04 & 0.03 & 2.05 & 0.13 & $4.69 \times 10^{-4}$ & 2.23 & 0.02 & 0.01 \\
\hline FE & g P eq & 0.85 & & 0.08 & $5.61 \times 10^{-3}$ & $2.02 \times 10^{-3}$ & $1.39 \times 10^{-3}$ & 0.18 & $3.86 \times 10^{-3}$ & $1.02 \times 10^{-4}$ & 0.59 & $8.37 \times 10^{-4}$ & $9.89 \times 10^{-4}$ \\
\hline $\mathrm{ME}$ & g N eq & 2.22 & 1.55 & 0.59 & $6.17 \times 10^{-4}$ & $1.30 \times 10^{-4}$ & $1.95 \times 10^{-4}$ & 0.01 & 0.03 & $7.58 \times 10^{-6}$ & $4.17 \times 10^{-2}$ & $5.54 \times 10^{-5}$ & $9.78 \times 10^{-5}$ \\
\hline TET & $\operatorname{kg} 1,4-\mathrm{DCB}$ & 2.24 & & 0.85 & 0.02 & $3.32 \times 10^{-2}$ & 0.01 & 0.91 & 0.05 & $9.80 \times 10^{-5}$ & 0.35 & 0.01 & $1.18 \times 10^{-3}$ \\
\hline FET & g 1,4-DCB & 79.65 & 50.07 & 4.83 & 0.16 & 0.66 & 0.04 & 8.29 & 0.18 & $2.92 \times 10^{-3}$ & 15.36 & 0.03 & 0.03 \\
\hline MRS & g Cu eq & 2.46 & & 0.95 & $5.81 \times 10^{-3}$ & 0.93 & $2.26 \times 10^{-3}$ & 0.22 & 0.02 & $3.02 \times 10^{-4}$ & 0.34 & $3.55 \times 10^{-4}$ & $3.83 \times 10^{-4}$ \\
\hline FRS & kg oil eq & 0.66 & & 0.07 & $2.67 \times 10^{-3}$ & $2.75 \times 10^{-3}$ & $1.17 \times 10^{-3}$ & 0.40 & 0.02 & $3.04 \times 10^{-5}$ & 0.16 & $3.00 \times 10^{-3}$ & $4.70 \times 10^{-3}$ \\
\hline $\mathrm{HT}, \mathrm{c}$ & $\times 10^{-10}$ CTUh & 2.20 & & 1.79 & $7.1 \times 10^{-3}$ & $3.73 \times 10^{-3}$ & $1.71 \times 10^{-3}$ & 0.28 & 0.01 & $2.67 \times 10^{-5}$ & $9.46 \times 10^{-2}$ & $5.71 \times 10^{-3}$ & 0.01 \\
\hline HT, nc & $\times 10^{-10}$ CTUh & 4.33 & & 3.13 & 0.02 & 0.05 & $4.56 \times 10^{-3}$ & 1.09 & 0.01 & $1.88 \times 10^{-5}$ & $2.11 \times 10^{-2}$ & $4.11 \times 10^{-4}$ & $4.15 \times 10^{-4}$ \\
\hline
\end{tabular}


Although there is some contribution from starch, VAc and direct emissions, there is a greater environmental influence from electricity consumption. If the inventory of this process is analyzed, it can be noted that the electricity requirements per $\mathrm{kg}$ of bioadhesive produced is 10 times higher (the processing time is also longer, being in this case $12 \mathrm{~h}$ of batch process, compared to $7 \mathrm{~h}$ for the first alternative studied). This is the reason why the contribution of electricity in the environmental profile is more noticeable for this second bioadhesive option. A promising and sustainable way to improve this environmental profile would be to consider the use of renewable energies, which would not only avoid the depletion of fossil resources but would also reduce the emissions associated with the raw material extraction processes and the production process itself.

\subsubsection{Alternative 3. Starch Bioadhesive Oxidized with $\mathrm{FeSO}_{4}$ and $\mathrm{H}_{2} \mathrm{O}_{2}$}

Both butyl acrylate (BAc) and vinyl acetate (VAc) account for more than $50 \%$ of the environmental contribution in most of the impact categories of this third alternative (Table 8 and Figure 4), with the exception of the SOD, ME and HT categories, where a higher impact influence of corn starch is perceived.

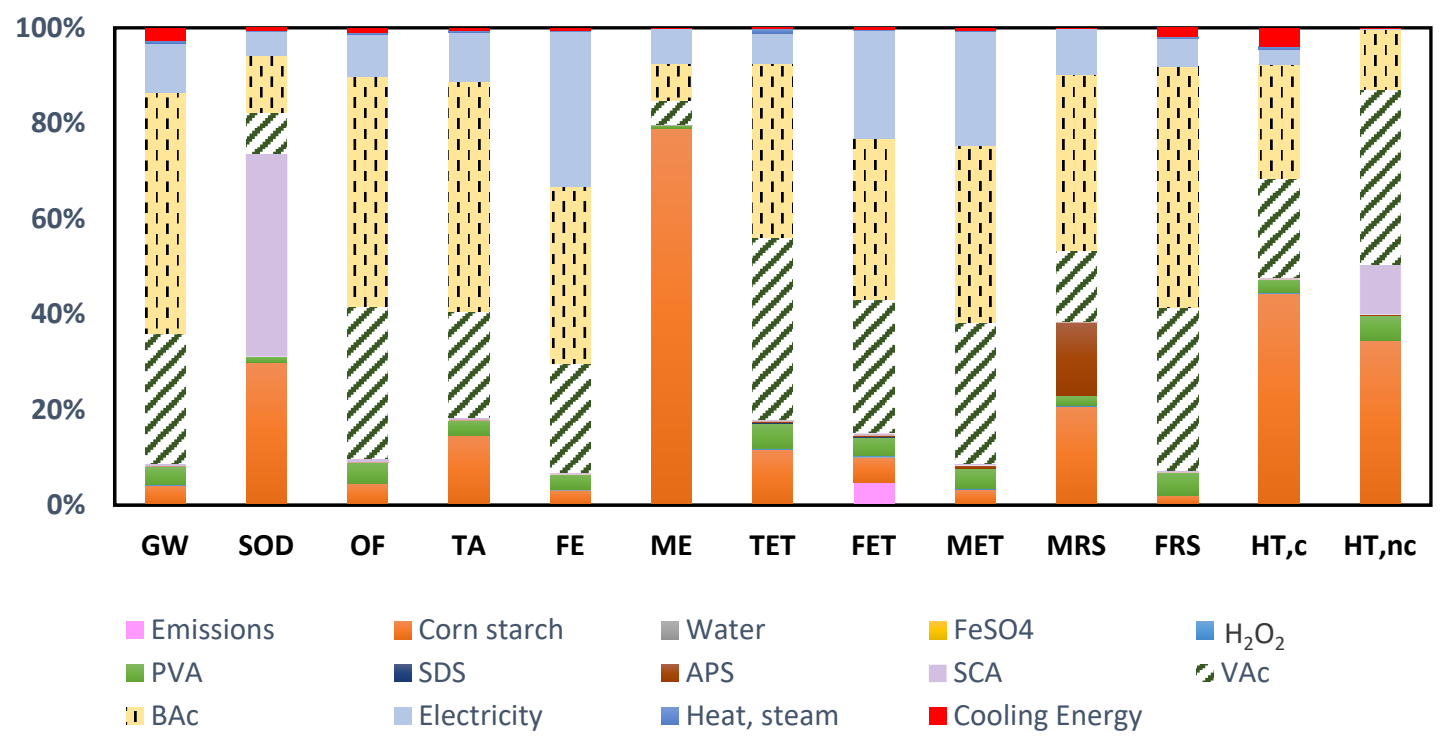

Figure 4. Environmental profile of the starch bioadhesive oxidized with $\mathrm{FeSO}_{4}$ and $\mathrm{H}_{2} \mathrm{O}_{2}$ (Alternative 3).

The background manufacturing activities of BAc and VAc are the reason for these high contributions on the environmental profile for this third bioadhesive alternative. As for BAc, it is produced by the esterification reaction of acrylic acid with methanol. Developing the LCA of its production, it is observed that methanol and the caloric requirements of the production process are the main hotspots of the environmental profile. On the other hand, when performing an in-depth analysis, regarding the methanol manufacturing process, which is based on the hydroformylation of propylene, the main contributors on its environmental profile are carbon monoxide, propylene and energy requirements. Therefore, this detailed analysis of BAc background activities allows us to identify that its contribution to the environmental profile of the starch bioadhesive is the result of the use of chemicals (methanol, carbon monoxide and propylene), which are the cause of the high contribution in categories such as GW, OF, TA, TET, FET and MET. On the other hand, thermal energy needs, obtained from nonrenewable fossil resources, are the cause of the impact in the MRS and FRS categories.

A similar procedure has been carried out to investigate the high contribution of VAc in the environmental profile obtained. The conclusion grasped after an exhaustive analysis of each of the stages of its production process, based on the reaction between ethylene and acetic acid, is that the chemicals with the greatest impact on the environment are acetic 
acid, carbon monoxide and methanol (mainly affecting the impact categories of ecotoxicity, eutrophication and climate change) and, on the other hand, the energy requirements, which contribute to the categories of scarcity of resources, both fossil and mineral.

\subsubsection{Alternative 4. Starch Bioadhesive Oxidized with $\mathrm{NaClO}$ and $\mathrm{ECH}$}

Specific details on the different impact categories are shown in Table 9. On the other hand, Figure 5 represents the environmental profile of the starch bioadhesive oxidized with $\mathrm{NaClO}$ and $\mathrm{ECH}$.

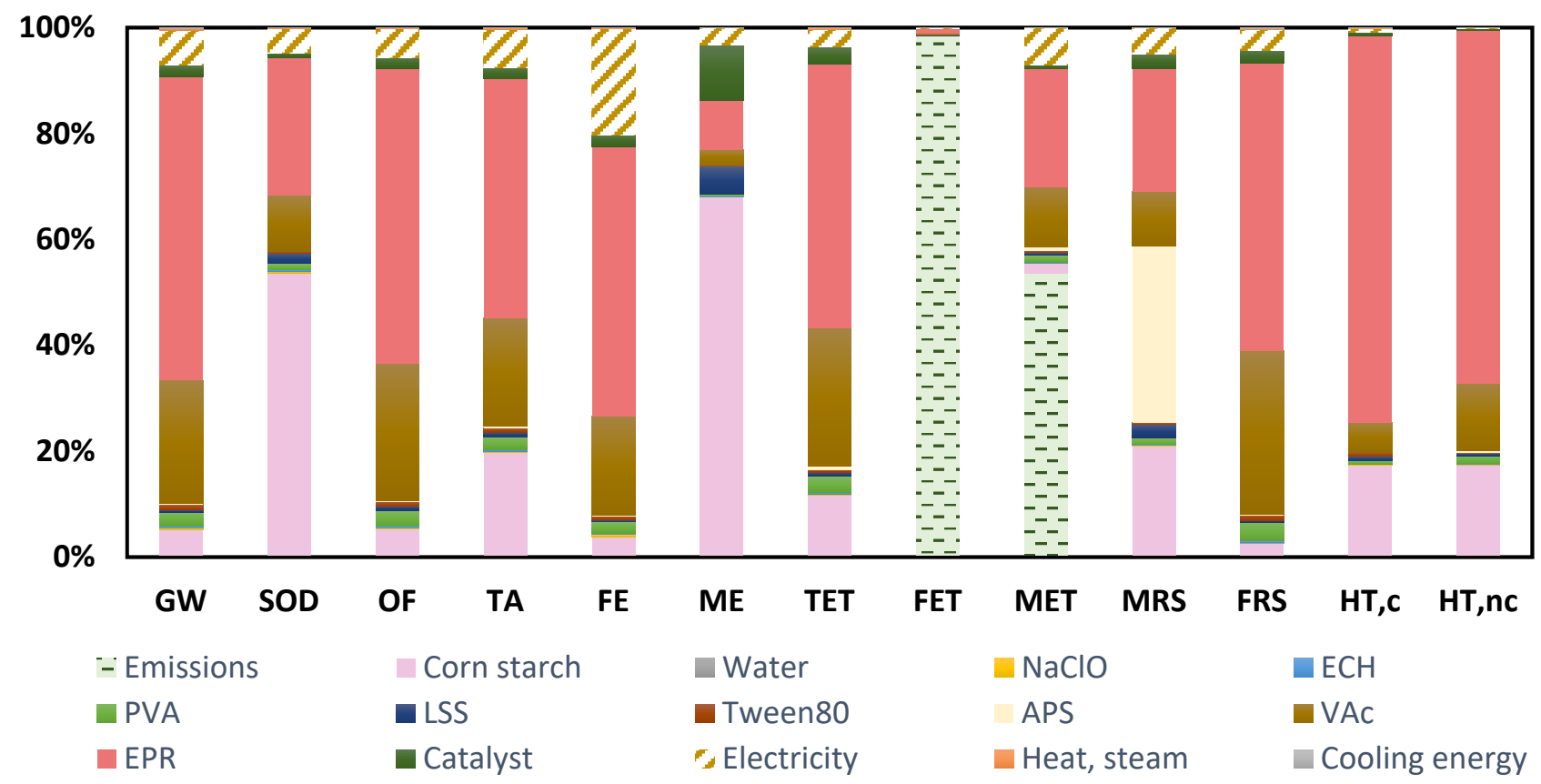

Figure 5. Environmental profile of the starch bioadhesive oxidized with $\mathrm{NaClO}$ and $\mathrm{ECH}$ (Alternative 4).

As can be seen, two main items stand out in most of the impact categories: epoxy resin and corn starch, except for FET, MET and MRS. Regarding the FET and MET categories, the emissions released within the bioadhesive production process are the ones with the highest environmental contribution. The use of $\mathrm{NaCl}, \mathrm{HCl}$ and $\mathrm{H}_{2} \mathrm{SO}_{4}$ is the reason for the high impact obtained in the categories of freshwater and marine ecosystem ecotoxicities. A suitable strategy of neutralization would allow to reduce the environmental contribution on these impact categories. As for corn starch, its influence on the environmental profile is the result of background activities, as analyzed in the previous profiles obtained for the other bioadhesive alternatives proposed here: fertilizer use in cultivation, energy use for machinery, among others. 
Table 8. Environmental characterization of starch bioadhesive oxidized with $\mathrm{FeSO}_{4}$ and $\mathrm{H}_{2} \mathrm{O}_{2}$.

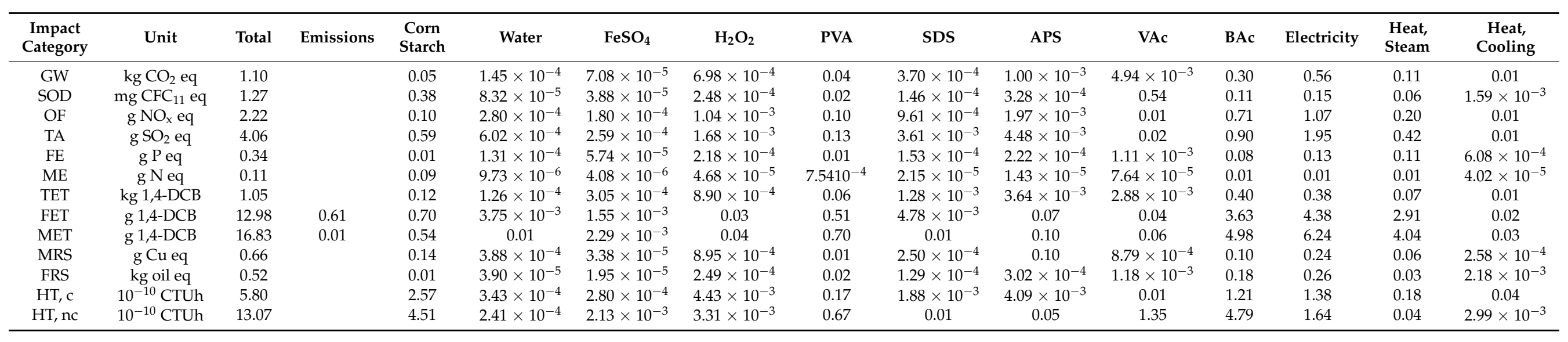

Table 9. Environmental characterization of starch bioadhesive oxidized with $\mathrm{NaClO}$ and $\mathrm{ECH}$.

\begin{tabular}{|c|c|c|c|c|c|c|c|c|c|c|c|c|c|c|c|c|c|}
\hline $\begin{array}{c}\text { Impact } \\
\text { Category }\end{array}$ & Unit & Total & Emissions & $\begin{array}{l}\text { Corn } \\
\text { starch }\end{array}$ & Water & $\mathrm{NaClO}$ & ECH & PVA & LSS & Tween80 & APS & VAc & EPR & Catalyst & Electricity & $\begin{array}{l}\text { Heat, } \\
\text { Steam }\end{array}$ & $\begin{array}{c}\text { Cooling } \\
\text { Energy }\end{array}$ \\
\hline GW & $\mathrm{kg} \mathrm{CO}_{2} \mathrm{eq}$ & 1.82 & & 0.09 & $9.38 \times 10^{-5}$ & $3.90 \times 10^{-3}$ & $6.90 \times 10^{-3}$ & 0.05 & $8.60 \times 10^{-3}$ & $1.83 \times 10^{-2}$ & $4.43 \times 10^{-3}$ & 0.42 & 1.04 & 0.04 & 0.12 & 0.01 & $2.63 \times 10^{-3}$ \\
\hline SOD & $\mathrm{mgCFC}_{11}$ eq & 1.45 & & 0.78 & $5.37 \times 10^{-5}$ & $4.78 \times 10^{-3}$ & $3.89 \times 10^{-3}$ & 0.02 & 0.03 & $4.27 \times 10^{-3}$ & $1.45 \times 10^{-3}$ & 0.15 & 0.38 & 0.01 & 0.07 & $1.47 \times 10^{-3}$ & $7.64 \times 10^{-4}$ \\
\hline OF & $\mathrm{g} \mathrm{NO}_{x}$ eq & 3.87 & & 0.20 & $1.80 \times 10^{-4}$ & 0.01 & 0.01 & 0.11 & 0.03 & 0.03 & 0.01 & 1.00 & 2.15 & 0.08 & 0.21 & 0.01 & $1.96 \times 10^{-3}$ \\
\hline TA & $\mathrm{g} \mathrm{SO}_{2} \mathrm{eq}$ & 6.21 & & 1.23 & $3.88 \times 10^{-4}$ & 0.01 & 0.02 & 0.15 & 0.06 & 0.05 & 0.02 & 1.27 & 2.81 & 0.13 & 0.45 & 0.01 & $2.29 \times 10^{-3}$ \\
\hline $\mathrm{FE}$ & $\mathrm{g} \mathrm{P} \mathrm{eq}$ & 0.59 & & 0.02 & $8.46 \times 10^{-5}$ & $2.17 \times 10^{-3}$ & $1.79 \times 10^{-3}$ & 0.01 & $2.21 \times 10^{-3}$ & $4.41 \times 10^{-3}$ & $9.81 \times 10^{-4}$ & 0.11 & 0.30 & 0.01 & 0.12 & $5.64 \times 10^{-4}$ & $1.90 \times 10^{-4}$ \\
\hline $\mathrm{ME}$ & $\mathrm{g} N$ eq & 0.26 & & 0.18 & $6.28 \times 10^{-6}$ & $2.30 \times 10^{-4}$ & $1.85 \times 10^{-4}$ & $8.65 \times 10^{-4}$ & 0.01 & $3.01 \times 10^{-4}$ & $6.31 \times 10^{-5}$ & 0.01 & 0.02 & 0.03 & 0.01 & $3.73 \times 10^{-5}$ & $1.88 \times 10^{-5}$ \\
\hline TET & $\mathrm{kg} 1,4-\mathrm{DCB}$ & 2.18 & & 0.25 & $8.11 \times 10^{-5}$ & $5.64 \times 10^{-3}$ & $8.69 \times 10^{-3}$ & 0.06 & $1.67 \times 10^{-2}$ & $1.12 \times 10^{-2}$ & $1.61 \times 10^{-2}$ & 0.57 & 1.09 & 0.07 & 0.07 & $8.54 \times 10^{-3}$ & $2.27 \times 10^{-4}$ \\
\hline FET & g 1,4-DCB & 1409 & 1386 & 1.43 & $2.42 \times 10^{-3}$ & 0.06 & 0.06 & 0.59 & 0.61 & 0.14 & 0.32 & 5.13 & 11.11 & 0.33 & 3.09 & 0.02 & 0.01 \\
\hline MET & g $1,4-\mathrm{DCB}$ & 61.74 & 33.11 & 1.10 & $3.38 \times 10^{-3}$ & 0.09 & 0.09 & 0.80 & 0.34 & 0.20 & 0.44 & 7.02 & 13.74 & 0.49 & 4.28 & 0.03 & 0.01 \\
\hline MRS & $\mathrm{g}$ Cu eq & 1.34 & & 0.28 & $2.50 \times 10^{-4}$ & $2.26 \times 10^{-3}$ & $2.35 \times 10^{-3}$ & 0.02 & 0.03 & $4.61 \times 10^{-3}$ & 0.45 & 0.14 & 0.31 & 0.04 & 0.07 & $2.39 \times 10^{-4}$ & $7.36 \times 10^{-5}$ \\
\hline $\mathrm{HT}, \mathrm{c}$ & $\times 10^{-10} \mathrm{CTUh}$ & 3.06 & & 0.53 & $2.21 \times 10^{-5}$ & $3.07 \times 10^{-3}$ & $2.97 \times 10^{-3}$ & $1.95 \times 10^{-2}$ & $2.47 \times 10^{-2}$ & $2.35 \times 10^{-2}$ & $1.81 \times 10^{-3}$ & 0.17 & 2.24 & $2.21 \times 10^{-2}$ & $1.89 \times 10^{-2}$ & $3.85 \times 10^{-3}$ & $2.07 \times 10^{-3}$ \\
\hline $\mathrm{HT}$, nc & $\times 10^{-10} \mathrm{CTUh}$ & 5.35 & & 0.93 & $1.55 \times 10^{-5}$ & $7.99 \times 10^{-3}$ & $7.27 \times 10^{-3}$ & $7.73 \times 10^{-2}$ & $2.41 \times 10^{-2}$ & $4.65 \times 10^{-3}$ & $2.33 \times 10^{-2}$ & 0.68 & 3.58 & $2.07 \times 10^{-2}$ & $4.20 \times 10^{-3}$ & $2.77 \times 10^{-4}$ & $7.96 \times 10^{-5}$ \\
\hline
\end{tabular}


Looking for the reason for such a high environmental contribution of the use of epoxy resin, the elements that make up its production process have been analyzed to determine if this high impact is the result of the use of chemical agents or if, on the contrary, it is due to the energy demand of its industrial production. Epoxy resin is produced from the reaction between bisphenol A and epichlorohydrin, both chemicals are obtained from nonrenewable fossil resources and are the main hotspots identified in the environmental profile. Regarding bisphenol A, it is produced by catalytic condensation between phenol and acetone. To evaluate the reason for its high impact, a detailed analysis of its manufacturing process is carried out, based on the Hock process [65], an autocatalytic and exothermic oxidation process that uses cumene as raw material, identifying cumene as the main hot spot in the environmental profile obtained. Thus, a final analysis was carried out for this chemical agent, obtained from the alkylation of benzene and propene and, once again, it was observed that the elements of the inventory that lead to a greater environmental impact are the chemical agents used for its production, given its nonrenewable nature. As for epichlorohydrin, the conclusions obtained by performing an analysis similar to the previous one are the same, although, in addition to the identification of chemical agents as the main contributors to the environmental impacts generated, the emissions associated with the production processes also have a significant influence, given that its most widespread form of waste management is through incineration, which gives rise to emissions of hazardous agents, such as carbon dioxide, methane, nitrates and phenolic compounds, among others.

Therefore, after this exhaustive analysis, it is concluded that the chemicals necessary for the formulation of this starch bioadhesive alternative are the main causes of environmental impacts.

\subsection{Comparison between Starch Bio-Based Adhesive Alternatives}

The impact results obtained after the environmental assessment have been used for the comparison of the four starch-based bioadhesive alternatives proposed by applying the Recipe Midpoint and USEtox calculation methodologies. As can be seen in Figure 6, Alternative 2 (starch bioadhesive hydrolyzed with N-methyl acrylamide) is the one with the highest potential environmental impact, being the most detrimental in most of the impact categories related to environmental quality. On the other hand, in the two categories specific for damage to human health, it is identified as the best alternative, since it has the least negative impact on health.

The second worst alternative, from an environmental point of view, is Alternative 4 (starch bioadhesive oxidized with $\mathrm{NaClO}$ and $\mathrm{ECH}$ ). In the ecotoxicity categories (FET, TET and MET), as well as in the GW and FRS categories, it has the highest impact values compared to the other three. The reason for its high contribution in these categories is based on the use of EPR as a crosslinking agent. In addition to requiring a significant amount per $\mathrm{kg}$ of bioadhesive produced $(0.22 \mathrm{~kg} / \mathrm{kg})$, its production process is highly dependent on nonrenewable fossil resources, and also uses certain chemical agents with high potential negative impacts on environmental quality, resulting in significant environmental contributions.

The best results were obtained for Alternatives 1 and 3, Alternative 1 (hydrolyzed starch bioadhesive with bio-oil) being the most promising in most of the impact categories studied, with the exception of MRS, ME and HT, c. The reason for its significant contribution to the MRS category derives from the energy requirements of the adhesive formulation process since five different temperatures are required throughout its $12 \mathrm{~h}$ batch process, which will entail a significant consumption of nonrenewable fossil resources. As for its impact on the ME category, it is the result of the emission of chlorinated compounds, since these emissions are higher than those of the other bioadhesive alternatives proposed. Finally, in the HT, c impact category (Figure 2), the background activities associated with corn starch are the hotspot in this category. Since this second alternative has the highest ratio of starch/bioadhesive of the four proposed alternatives (0.44:1), its environmental impact in this USEtox category is also the most significant. 


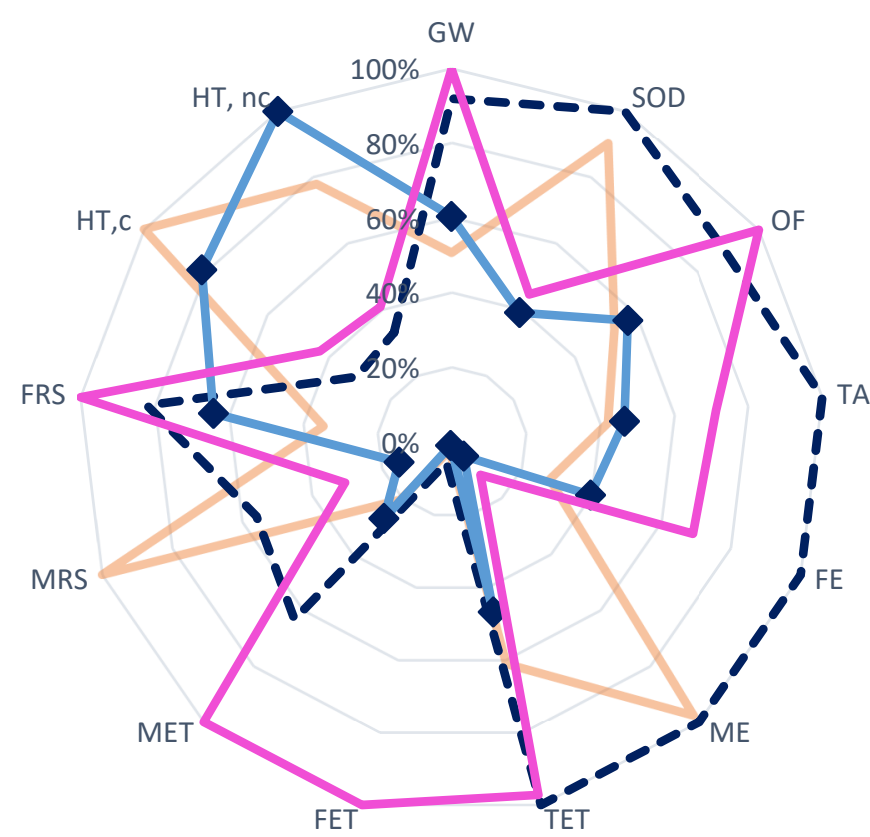

Alternative $1 \multimap$ Alternative $2 \leadsto$ Alternative $3 \leadsto$ Alternative 4

Figure 6. Comparative analysis of the starch bioadhesives alternatives.

The results obtained for Alternative 3 also show the high potential of this bioadhesive from an environmental sustainability point of view, as its life cycle assessment has resulted in low impact values for most of the categories studied, except for HT, nc, where it is identified as the bioadhesive alternative with the highest impact. The use of VAc and BAc in its formulation is what leads to the emerging toxicity of this third alternative. Therefore, one way to reduce its impact, and thus improve its quality and consider it a safe option for human health, would be to use other polymerization agents, such as PVA, which has shown low levels of impact in different environmental categories.

\subsection{Comparison with Synthetic Resins}

To analyze whether bio-based starch bioadhesives are potential options to substitute synthetic resins, it is important to perform a comparative analysis between conventional processes and those under development. It must be considered that the fact of being called bio-based does not necessarily imply that the associated environmental impacts are always lower, taking into account that the large-scale production process has yet to be optimized. Therefore, obtaining lower impact results compared to synthetic resins would be an important stage in the field of bioadhesives as it implies their great opportunity of application and presence in the market, given their wide range of adaptability, improvement and refinement, since their manufacturing processes are still in a first degree of development.

To perform this comparison between starch bioadhesives and synthetic resins (UF, PF and MUF), the Endpoint V1.03 method has been used. The inventory data to develop the LCA of petrochemical adhesives have been taken from the Ecoinvent database (for UF and PF) and from Silva et al. (2015) [66]. The application of this calculation methodology provides three final scores, embodied under the categories of human health, ecosystems and resources. These three scores encompass midpoint categories by considering particular endpoint characterization factors, which are shown in Figure 7. 


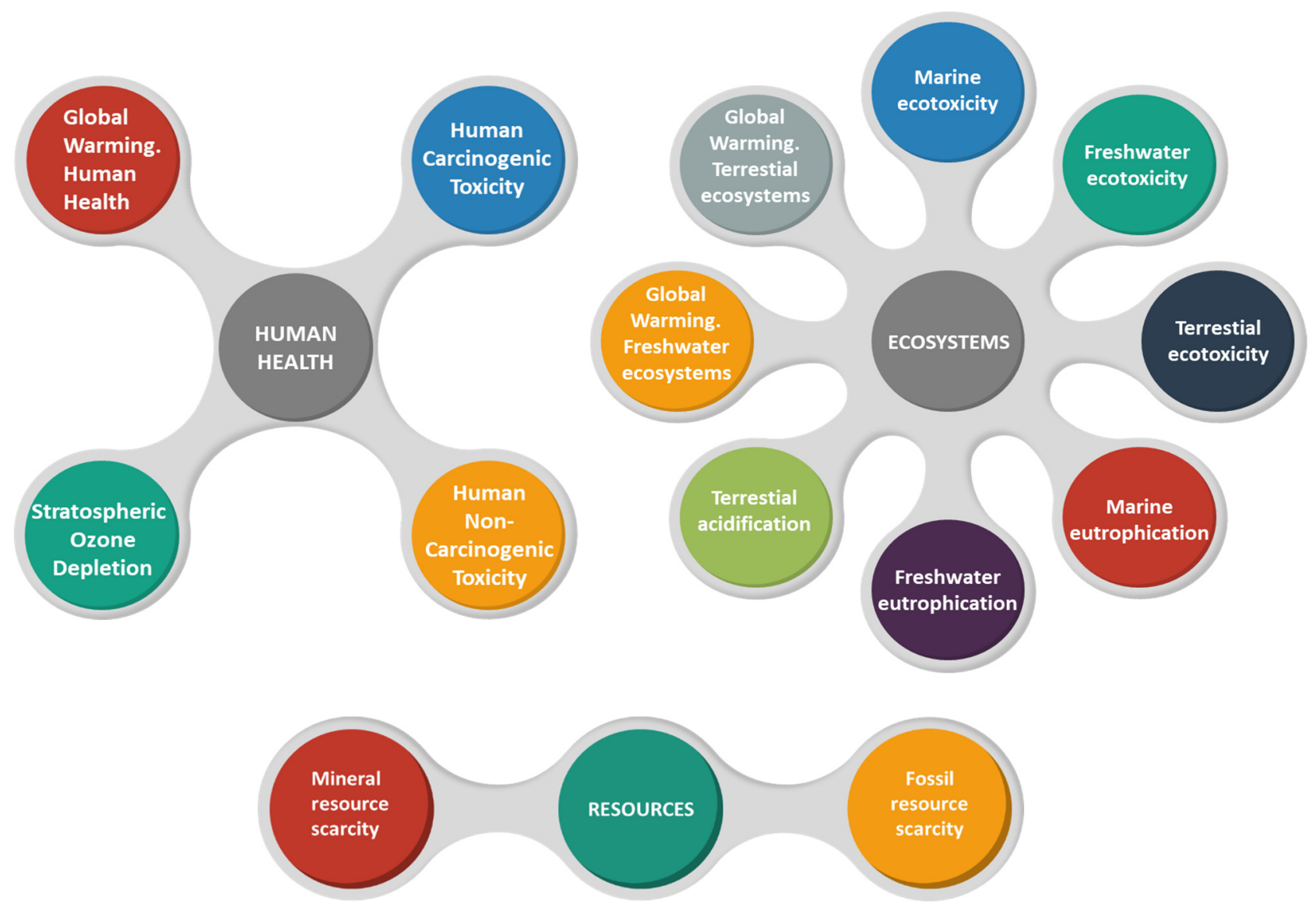

Figure 7. Endpoint characterization factors with midpoint categories and single score value calculation procedure.

In this way, the environmental profiles of the proposed adhesive alternatives can be viewed in a more condensed and simple manner, thus facilitating their final comparison. In addition, by applying normalization factors, it is possible to obtain a final value, known as a single score, which includes the three categories mentioned, thus providing a global view of the impact caused by the development of each of the options proposed in this article.

The results obtained are plotted in Figure 8 so that the upper figure shows the endpoint scores for the starch bioadhesives and the synthetic resins, and the lower figure shows the single score values.

Outstanding results were obtained for the starch bioadhesives proposed in this article, comparing their final scores with those of the synthetic resins. All bioadhesives present lower impact values in the human health and resource scarcity categories, with Alternatives 1 and 3 standing out, Alternative 1 being the one that achieved a better environmental result, as it is the starch bio-based adhesive alternative with the lowest single score value. On the other hand, higher impact scores have been obtained in the ecosystems category, although with values analogous to those of the PF synthetic resin and lower than those obtained for the MUF, but not by a value that implies that the proposed starch bioadhesives can be neglected.

The individual scores of the synthetic resins are considerably higher than those of the starch bioadhesives. According to the values obtained, MUF is the most environmentally friendly petrochemical-based resin alternative, as it presented the lowest single score value and, therefore, its production process entails a lower degree of environmental impact. However, when compared to the results obtained for the bio-based resins, the single score of MUF is even higher than all of them. This could be considered as an indicator of the high applicability potential of starch bioadhesives to replace synthetic ones, given that their formulation processes provide a significantly lower environmental contribution, the 
reduction of the consumption of nonrenewable resources, the use of agroindustrial waste streams and a more favorable impact in terms of human health.
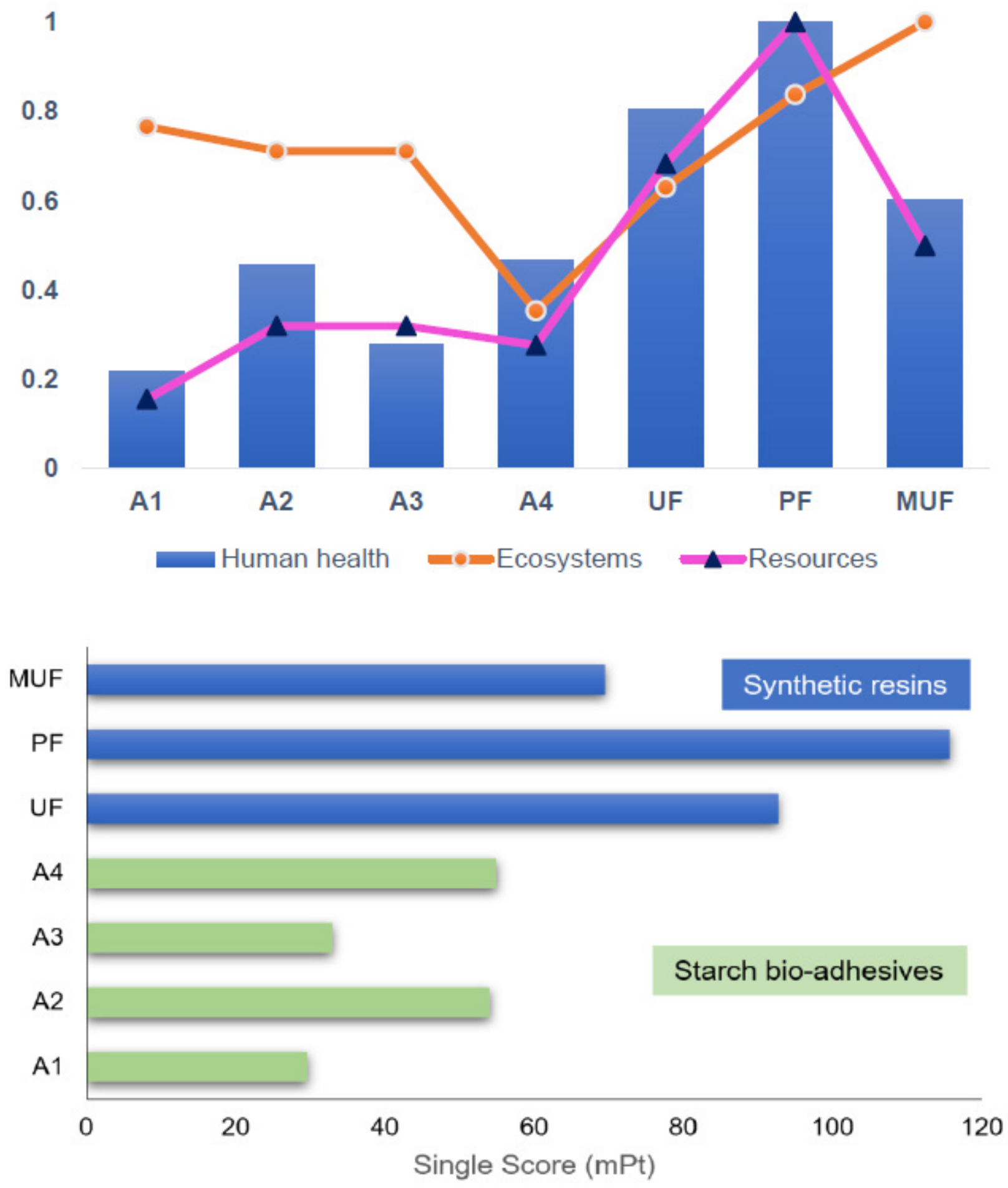

Figure 8. Endpoint characterization values obtained for the starch bioadhesives and synthetic resins.

\section{Conclusions}

In this report, the life cycle assessment methodology has been selected to evaluate the environmental performance of four starch-based bioadhesive alternatives as possible substitutes for the most widespread synthetic resins for wood-based panels: UF, PF and MUF. In order to develop the necessary inventories for the application of the above method- 
ology, a first large-scale simulation design was required, considering the experimental data available in the literature. The results obtained showed the enormous potential of starch bioadhesives, in terms of low environmental impacts caused by their production process compared to petrochemicals. Single score values of starch-based bioadhesives (Alternative 1: $30 \mathrm{mPt}$, Alternative 2: $54 \mathrm{mPt}$, Alternative 3: $33 \mathrm{mPt}$ and Alternative 4: $55 \mathrm{mPt}$ ) are significantly lower than the ones obtained for formaldehyde-based adhesives, with 93, 116 and $70 \mathrm{mPt}$ values for UF, PF and MUF adhesives, respectively.

However, according to the environmental profiles analyzed for each of the bio-based alternatives, certain improvements could be developed to provide even better results: optimization of energy requirements and reduction of certain chemical agents, due to their toxicity (i.e., BAc and VAc).

Thus, further research could be developed to further improve this proposed wood adhesive alternative from an environmental point of view. In addition, it would be desirable to develop research based on considering the durability and longevity of bio-based starch adhesives, in order to provide knowledge on appropriate and compatible treatments to be applied to wood-based panels to ensure their quality and strength. The hotspots identified in the environmental profiles could be useful for researchers and policy makers to move forward towards the framework of sustainable and formaldehyde-free wood adhesive alternatives.

Author Contributions: A.A.: methodology, formal analysis, investigation, writing-original draft. G.F.: writing—review \& editing. M.T.M.: conceptualization, supervision, writing-review \& editing. All authors have read and agreed to the published version of the manuscript.

Funding: This research has been financially supported by ERA-CoBIOTECH project (PCI2018-092866) Programación Conjunta Internacional 2018-WooBAdh project. The authors belong to the Galician Competitive Research Group (GRC ED431C 2017/29) and to CRETUS Strategic Partnership (ED431E 2018/01).

Institutional Review Board Statement: Not applicable.

Informed Consent Statement: Not applicable.

Data Availability Statement: Not applicable.

Acknowledgments: This research has been financially supported by ERA-CoBIOTECH project (PCI2018-092866) Programación Conjunta Internacional 2018-WooBAdh project. The authors belong to the Galician Competitive Research Group (GRC ED431C 2017/29) and to CRETUS Strategic Partnership (ED431E 2018/01).

Conflicts of Interest: The authors declare that they have no known competing financial interest or personal relationships that could have appeared to influence the work reported in this paper.

Sample Availability: Not available.

\section{References}

1. Zhang, L. CHAPTER 1: Introduction to Formaldehyde. In Issues in Toxicology; Royal Society of Chemistry: London, UK, 2018; Volume 2018.

2. Solt, P.; Konnerth, J.; Gindl-Altmutter, W.; Kantner, W.; Moser, J.; Mitter, R.; van Herwijnen, H.W.G. Technological performance of formaldehyde-free adhesive alternatives for particleboard industry. Int. J. Adhes. Adhes. 2019, 94, 99-131. [CrossRef]

3. Popović, M.; Điporovic-Momčilović, M.; Gavrilović-Grmuša, I. New standards and regulations on formaldehyde emission from wood-based composite panels. Zast. Mater. 2020, 61. [CrossRef]

4. Zhang, J.; Song, F.; Tao, J.; Zhang, Z.; Shi, S.Q. Research Progress on Formaldehyde Emission of Wood-Based Panel. Int. J. Polym. Sci. 2018, 2018, 9349721. [CrossRef]

5. Costa, N.A.; Pereira, J.; Ferra, J.; Cruz, P.; Martins, J.; Magalhães, F.D.; Mendes, A.; Carvalho, L.H. Scavengers for achieving zero formaldehyde emission of wood-based panels. Wood Sci. Technol. 2013, 47. [CrossRef]

6. Antov, P.; Savov, V.; Neykov, N. Reduction of formaldehyde emission from engineered wood panels by formaldehyde scavengersA review. In Proceedings of the Sustainability of Forest-Based Industries in the Global Economy_Proceedings of Scientific Papers; Elsevier: Vinkovci, Croatia, 2020.

7. Barbu, M.C.; Lohninger, Y.; Hofmann, S.; Kain, G.; Petutschnigg, A.; Tudor, E.M. Larch bark as a formaldehyde scavenger in thermal insulation panels. Polymers 2020, 12, 2632. [CrossRef] [PubMed] 
8. Duan, H.; Qiu, T.; Guo, L.; Ye, J.; Li, X. The microcapsule-type formaldehyde scavenger: The preparation and the application in urea-formaldehyde adhesives. J. Hazard. Mater. 2015, 293. [CrossRef] [PubMed]

9. Puttasukkha, J.; Khongtong, S.; Chaowana, P. Curing behavior and bonding performance of urea formaldehyde resin admixed with formaldehyde scavenger. Wood Res. 2015, 60, 645-654.

10. Zhang, Y.; Shi, R.; Xu, Y.; Chen, M.; Zhang, J.; Gao, Q.; Li, J. Developing a stable high-performance soybean meal-based adhesive using a simple high-pressure homogenization technology. J. Clean. Prod. 2020, 256. [CrossRef]

11. Chen, S.; Chen, Y.; Wang, Z.; Chen, H.; Fan, D. Renewable bio-based adhesive fabricated from a novel biopolymer and soy protein. RSC Adv. 2021, 11, 11724-11731. [CrossRef]

12. Arias, A.; González-García, S.; Feijoo, G.; Moreira, M.T. Environmental benefits of soy-based bio-adhesives as an alternative to formaldehyde-based options. Environ. Sci. Pollut. Res. 2021, 1-14. [CrossRef]

13. Ghahri, S.; Chen, X.; Pizzi, A.; Hajihassani, R.; Papadopoulos, A.N. Natural tannins as new cross-linking materials for soy-based adhesives. Polymers 2021, 13, 595. [CrossRef] [PubMed]

14. Horito, M.; Kurushima, N.; Ono, K.; Yazaki, Y. Plywood adhesives using PF resin with fibrillated bark slurry from radiata pine (Pinus radiata D. Don): Utilization of flavonoid compounds from bark and wood. IV. J. Wood Sci. 2020, 66. [CrossRef]

15. Matsumae, T.; Horito, M.; Kurushima, N.; Yazaki, Y. Development of bark-based adhesives for plywood: Utilization of flavonoid compounds from bark and wood. II. J. Wood Sci. 2019, 65. [CrossRef]

16. Alonso, M.V.; Oliet, M.; Rodríguez, F.; García, J.; Gilarranz, M.A.; Rodríguez, J.J. Modification of ammonium lignosulfonate by phenolation for use in phenolic resins. Bioresour. Technol. 2005. [CrossRef] [PubMed]

17. Yuan, Y.; Guo, M.; Liu, F. Preparation and evaluation of green composites using modified ammonium lignosulfonate and polyethylenimine as a binder. BioResources 2014, 9, 836-848. [CrossRef]

18. Antov, P.; Savov, V.; Krišt'ák, L.; Réh, R.; Mantanis, G.I. Eco-friendly, high-density fiberboards bonded with urea-formaldehyde and ammonium lignosulfonate. Polymers 2021, 13, 220. [CrossRef] [PubMed]

19. Yin, H.; Zheng, P.; Zhang, E.; Rao, J.; Lin, Q.; Fan, M.; Zhu, Z.; Zeng, Q.; Chen, N. Improved wet shear strength in eco-friendly starch-cellulosic adhesives for woody composites. Carbohydr. Polym. 2020, 250. [CrossRef]

20. Owodunni, A.A.; Lamaming, J.; Hashim, R.; Taiwo, O.F.A.; Hussin, M.H.; Mohamad Kassim, M.H.; Bustami, Y.; Sulaiman, O.; Amini, M.H.M.; Hiziroglu, S. Adhesive application on particleboard from natural fibers: A review. Polym. Compos. 2020, 41, 4448-4460. [CrossRef]

21. Baishya, P.; Maji, T.K. Studies on effects of different cross-linkers on the properties of starch-based wood composites. ACS Suatain. Chem. Eng. 2014, 2, 1760-1768. [CrossRef]

22. Zheng, P.; Zeng, Q.; Lin, Q.; Fan, M.; Zhou, J.; Rao, J.; Chen, N. Investigation of an ambient temperature-curable soy-based adhesive for wood composites. Int. J. Adhes. Adhes. 2019. [CrossRef]

23. Moubarik, A.; Pizzi, A.; Allal, A.; Charrier, F.; Charrier, B. Cornstarch and tannin in phenol-formaldehyde resins for plywood production. Ind. Crops Prod. 2009. [CrossRef]

24. Lubis, M.A.R.; Yadav, S.M.; Park, B.D. Modification of Oxidized Starch Polymer with Nanoclay for Enhanced Adhesion and Free Formaldehyde Emission of Plywood. J. Polym. Environ. 2021. [CrossRef]

25. Sun, J.; Li, L.; Cheng, H.; Huang, W. Preparation, characterization and properties of an organic siloxane-modified cassava starch-based wood adhesive. J. Adhes. 2018, 94. [CrossRef]

26. Gadhave, R.V.; Mahanwar, P.A.; Gadekar, P.T. Starch-Based Adhesives for Wood/Wood Composite Bonding: Review. Open J. Polym. Chem. 2017. [CrossRef]

27. Monroy, Y.; Rivero, S.; García, M.A. Sustainable panels design based on modified cassava starch bioadhesives and wood processing byproducts. Ind. Crops Prod. 2019, 137. [CrossRef]

28. Arias, A.; González-García, S.; González-Rodríguez, S.; Feijoo, G.; Moreira, M.T. Cradle-to-gate Life Cycle Assessment of bio-adhesives for the wood panel industry. A comparison with petrochemical alternatives. Sci. Total Environ. 2020. [CrossRef] [PubMed]

29. ISO 14040: 2006. Environmental Management-Life Cycle Assessment-Principles and Framework. Available online: https: / / www.iso.org/standard/37456.html (accessed on 21 July 2021).

30. Bongono, J.; Elevli, B.; Laratte, B. Functional unit for impact assessment in the mining sector-Part 1. Sustainability 2020, $12,9313$. [CrossRef]

31. Cao, C. Sustainability and life assessment of high strength natural fibre composites in construction. In Advanced High Strength Natural Fibre Composites in Construction; Woodhead Publishing: Sawston, UK, 2017; ISBN 9780081004302.

32. Wernet, G.; Bauer, C.; Steubing, B.; Reinhard, J.; Moreno-Ruiz, E.; Weidema, B. The ecoinvent database version 3 (part I): Overview and methodology. Int. J. Life Cycle Assess. 2016, 21. [CrossRef]

33. Chen, P.; Xie, F.; Zhao, L.; Qiao, Q.; Liu, X. Effect of acid hydrolysis on the multi-scale structure change of starch with different amylose content. Food Hydrocoll. 2017, 69, 359-368. [CrossRef]

34. Gu, J.; Zuo, Y.; Zhang, Y.; Tan, H.; Zhu, L.; Shen, J. Preparation of plywood using starch adhesives modified with isocyanate. Proc. Appl. Mech. Mater. 2010, 26-28, 1065-1068. [CrossRef]

35. Cheng, E.; Sun, X. Effects of wood-surface roughness, adhesive viscosity and processing pressure on adhesion strength of protein adhesive. J. Adhes. Sci. Technol. 2006, 20, 997-1017. [CrossRef] 
36. Haroon, M.; Wang, L.; Yu, H.; Abbasi, N.M.; Zain-Ul-Abdin; Saleem, M.; Khan, R.U.; Ullah, R.S.; Chen, Q.; Wu, J. Chemical modification of starch and its application as an adsorbent material. RSC Adv. 2016, 6, 78264-78285. [CrossRef]

37. Xing, J.; Li, T.; Yu, Y.; Chen, C.; Chang, J. Development and characterization of a new bio-adhesive for wood using cassava starch and bio-oil. Int. J. Adhes. Adhes. 2018, 87. [CrossRef]

38. Xu, Q.; Wen, J.; Wang, Z. Preparation and properties of cassava starch-based wood adhesives. BioResources 2016. [CrossRef]

39. Tang, X.; Alavi, S. Recent advances in starch, polyvinyl alcohol based polymer blends, nanocomposites and their biodegradability. Carbohydr. Polym. 2011, 85, 7-16. [CrossRef]

40. Chen, N.; Zeng, Q.; Lin, Q.; Rao, J. Effect of Enzymatic Pretreatment on the Preparation and Properties of Soy-Based Adhesive for Plywood. BioResources 2015, 10. [CrossRef]

41. Zia-ud-Din; Chen, L.; Ullah, I.; Wang, P.K.; Javaid, A.B.; Hu, C.; Zhang, M.; Ahamd, I.; Xiong, H.; Wang, Z. Synthesis and characterization of starch-g-poly(vinyl acetate-co-butyl acrylate) bio-based adhesive for wood application. Int. J. Biol. Macromol. 2018, 114. [CrossRef]

42. Ibrahim, M.M.; Moustafa, H.; El Rahman, E.N.A.; Mehanny, S.; Hemida, M.H.; El-Kashif, E. Reinforcement of starch based biodegradable composite using Nile rose residues. J. Mater. Res. Technol. 2020, 9. [CrossRef]

43. Gu, Y.; Cheng, L.; Gu, Z.; Hong, Y.; Li, Z.; Li, C. Preparation, characterization and properties of starch-based adhesive for wood-based panels. Int. J. Biol. Macromol. 2019. [CrossRef]

44. Schmidt, B.; Kowalczyk, K.; Zielinska, B. Synthesis and characterization of novel hybrid flocculants based on potato starch copolymers with hollow carbon spheres. Materials 2021, 14, 1498. [CrossRef]

45. Fortuna, T.; Juszczak, L.; Pietrzyk, S.; Wróbel, M. Physico-chemical properties of oxidized starches of different origin. Polish J. Food Nutr. Sci. 2002, 2, 11-52.

46. Lewicka, K.; Siemion, P.; Kurcok, P. Chemical modifications of starch: Microwave effect. Int. J. Polym. Sci. 2015, 2015, 867697. [CrossRef]

47. Han, B. Properties of Oxidized Starch Prepared by Hydrogen Peroxide, Chlorine Dioxide and Sodium Hypochlorite. In Proceedings of the 2016 International Conference on Biomedical and Biological Engineering, Shanghai, China, 15-17 July 2016.

48. Briffa, J.; Sinagra, E.; Blundell, R. Heavy metal pollution in the environment and their toxicological effects on humans. Heliyon 2020, 6, e04691. [CrossRef] [PubMed]

49. Kalambur, S.; Rizvi, S.S.H. An overview of starch-based plastic blends from reactive extrusion. J. Plast. Film Sheeting 2006, 22, 39-58. [CrossRef]

50. Zhang, Y.; Ding, L.; Gu, J.; Tan, H.; Zhu, L. Preparation and properties of a starch-based wood adhesive with high bonding strength and water resistance. Carbohydr. Polym. 2015. [CrossRef] [PubMed]

51. Wang, M.; Yuan, D.; Fan, X.; Sahoo, N.G.; He, C. Polymer nanocomposite hydrogels exhibiting both dynamic restructuring and unusual adhesive properties. Langmuir 2013, 29. [CrossRef] [PubMed]

52. Li, Z.; Wang, J.; Cheng, L.; Gu, Z.; Hong, Y.; Kowalczyk, A. Improving the performance of starch-based wood adhesive by using sodium dodecyl sulfate. Carbohydr. Polym. 2014, 99, 579-583. [CrossRef] [PubMed]

53. Wang, Z.; Gu, Z.; Li, Z.; Hong, Y.; Cheng, L. Effects of emulsifier on the bonding performance and freeze-thaw stability of starch-based wood adhesive. Cellulose 2013, 20. [CrossRef]

54. Norström, E.; Demircan, D.; Fogelström, L.; Khabbaz, F.; Malmström, E. Green Binders for Wood Adhesives. In Applied Adhesive Bonding in Science and Technology; InTech: London, UK, 2018.

55. Gadhave, R.V.; Sheety, P.; Mahanwar, P.A.; Gadekar, P.T.; Desai, B.J. Silane Modification of Starch-Based Wood Adhesive: Review. Open J. Polym. Chem. 2019, 9. [CrossRef]

56. Wu, Y.; Lv, C.; Han, M. Synthesis and performance study of polybasic starch graft copolymerization function materials. Proc. Adv. Mater. Res. 2009, 79-82, 43-46. [CrossRef]

57. Patel, K.F.; Mehta, H.U.; Srivastava, H.C. Kinetics and mechanism of oxidation of starch with sodium hypochlorite. J. Appl. Polym. Sci. 1974, 18. [CrossRef]

58. Nie, Y.; Tian, X.; Liu, Y.; Wu, K.; Wang, J. Research on starch-g-polyvinyl acetate and epoxy resin-modified corn starch adhesive. Polym. Compos. 2013, 34. [CrossRef]

59. Kuniak, L.; Marchessault, R.H. Study of the Crosslinking Reaction between Epichlorohydrin and Starch. Starch Stärke 1972, 24. [CrossRef]

60. Din, Z.; Chen, L.; Xiong, H.; Wang, Z.; Ullah, I.; Lei, W.; Shi, D.; Alam, M.; Ullah, H.; Khan, S.A. Starch: An Undisputed Potential Candidate and Sustainable Resource for the Development of Wood Adhesive. Starch-Staerke 2020, 72, 1900276. [CrossRef]

61. Müller, B.; Rath, W. Formulating Adhesives and Sealants; Vincentz Network: Hannover, Germany, 2019.

62. USDA. NOP National Organic Program / Agricultural Marketing Service. Available online: https://www.ams.usda.gov/aboutams/programs-offices/national-organic-program (accessed on 20 July 2021).

63. Daryl Quinlivan Greenhouse Effect I Department of Agriculture, Water and the Environment. Department of Agriculture, Water and the Environment. 2020. Available online: https:/ / www.awe.gov.au/sites/default/files/2020-10/annual-report-2019-20awe-oct-2020.pdf (accessed on 20 July 2021).

64. Babaee, S.; Loughlin, D.H.; Kaplan, P.O. Incorporating upstream emissions into electric sector nitrogen oxide reduction targets. Clean. Eng. Technol. 2020, 1. [CrossRef] 
65. Rhee, H.K.; Nam, I.S.; Jong, M.P. New developments and application in chemical reaction engineering: Preface. In Proceedings of the Studies in Surface Science and Catalysis; Elsevier: Amsterdam, The Netherlands, 2006; Volume 159.

66. Silva, D.A.L.; Lahr, F.A.R.; Varanda, L.D.; Christoforo, A.L.; Ometto, A.R. Environmental performance assessment of the melamine-urea-formaldehyde (MUF) resin manufacture: A case study in Brazil. J. Clean. Prod. 2015. [CrossRef] 